\title{
Neuroendocrine tumors: current therapies, notch signaling, and cancer stem cells
}

\author{
Judy S. Crabtree, Lucio Miele \\ Department of Genetics and Stanley S. Scott Cancer Center, Louisiana State University Health Sciences Center, New Orleans, LA 70112, USA.
}

Correspondence to: Dr. Judy S. Crabtree, Department of Genetics, Louisiana State University Health Sciences Center, 533 Bolivar Street, New Orleans, LA 70112, USA. E-mail: jcrabt@1suhsc.edu

\section{A B S T R A C T}

Neuroendocrine tumors (NETs) encompass a broad spectrum of malignancies all derived from neuroendocrine cell lineage, affecting many different organs including the gastrointestinal (GI) tract, the endocrine pancreas, the thyroid, the skin and the respiratory tract. These tumors as a group are very heterogeneous, with varying characteristics attributed to each tissue of origin and tumor subtype. The pathogenesis of the different subtypes of NETs is not fully understood, but recent studies suggest the Notch signaling pathway may be dysregulated in these tumors either by under or overexpression of Notch receptors and/or ligands, or by disruption of pathway functionality through other means. Notch receptors can function as tumor suppressors in some cellular contexts and oncogenes in others which may, in part, account for the wide range of phenotypes present in NETs. Cancer stem cells are present in these tumors and may be responsible for the high rate of chemotherapy resistance, recurrence and metastasis. The heterogeneity of NETs suggests that to fully understand the role of Notch signaling and the therapeutic implications thereof, a comprehensive and systematic analysis of Notch expression and function across all NET subtypes is required. Here we outline the current knowledge base with respect to current therapies and Notch signaling in neuroendocrine tumors of the lung, skin, thyroid, GI tract and endocrine pancreas.

Key words: Neuroendocrine tumor; Notch; small cell lung carcinoma; medullary thyroid carcinoma; merkel cell carcinoma; pancreatic NET; carcinoid

\section{INTRODUCTION}

Neuroendocrine tumors (NETs) are a heterogeneous group of neoplasms that arise from the neuroendocrine cells of the gastrointestinal (GI) tract, endocrine pancreas, thyroid, skin, lung, adrenal gland and other tissues. These tumors are typically slow-growing, yet pose a significant threat due to high metastatic potential. In many cases, patients initially present with advanced metastatic disease resulting in poor outcomes and low 5-year survival rates. An understanding of the mechanism(s) of tumorigenesis and metastasis is required for target identification and new therapeutic development, since many NET subtypes have no curative options beyond surgical resection.

In recent years, studies have suggested that the Notch signaling pathway may be involved in the pathogenesis of NETs. Notch signaling has been studied for many years in the context of cancer and as these pathways are dissected, the complexity of Notch signaling becomes

\begin{tabular}{|l|l|}
\hline \multicolumn{2}{|c|}{ Access this article online } \\
\hline Quick Response Code: & Website: \\
\hline & www.jcmtjournal.com \\
\cline { 2 - 2 } & \\
\hline
\end{tabular}

more and more evident. Notch signaling is classified into two broad categories: 1) canonical signaling, wherein Notch receptors regulate transcription through CSL (CBF1/Suppressor of Hairless/LAG-1), also known as RBP$\mathrm{Jk}$, and can play an oncogenic or tumor suppressive role depending on context, or 2) non-canonical, which functions through interplay with other signaling networks including phosphatidylinositol 3' kinase (PI3K)/Akt, mTOR, NF$\mathrm{kB}$ and beta-catenin. ${ }^{[1-6]}$ In NETs, interactions with these pathways as well as complexes between canonical Notch target hairy enhancer of split 1 (Hes1) and achaete-schute complex-like 1 (ASCL-1) have been reported..$^{[7-14]}$ Many of these pathways can be pharmacologically modulated for translational research and eventually for experimental therapy of NETs, once the role of Notch signaling in these tumors is more clearly elucidated. Here we review the current state of NET therapies, the role of canonical and non-canonical Notch signaling in these tumor types,

This is an open access article distributed under the terms of the Creative Commons Attribution-NonCommercial-ShareAlike 3.0 License, which allows others to remix, tweak, and build upon the work non-commercially, as long as the author is credited and the new creations are licensed under the identical terms.

For reprints contact: service@oaepublish.com

How to cite this article: Crabtree JS, Miele L. Neuroendocrine tumors: current therapies, notch signaling, and cancer stem cells. J Cancer Metasta Treat 2016;2:279-93.

Received: 02-06-2016; Accepted: 01-08-2016. 
and the role of cancer stem cells in NET pathogenesis, chemoresistance and recurrence.

\section{NOTCH SIGNALING}

The Notch signaling pathway is an evolutionarily conserved, critical component of basic cellular processes such as proliferation, stem cell maintenance, and differentiation during both embryonic and adult development. The canonical Notch signaling pathway has been well-studied and typically depends on the binding of a Notch receptor to its ligand residing on a neighboring cell. This ligand binding promotes the separation of the extracellular subunit from the transmembrane subunit, which is followed by cleavage of the receptor's transmembrane subunit by ADAM metalloproteases (primarily ADAM-10) and gamma secretase. The latter cleavage releases the active form of Notch, the Notch intracellular domain (NICD). The NICD then translocates into the nucleus and binds to the transcription factor CSL (CBF-1/Suppressor of Hairless/LAG1), also known as RBP-Jk, to control expression of Notch-regulated genes. ${ }^{[15-18]}$ Ligand-independent activation of Notch cleavage has been reported in some contexts, notably breast cancer stem cells, where it is mediated by activation of ADAM-17 via the Sphingosine 1-phosphate pathway. ${ }^{[19]}$

Different species contain different numbers of Notch isoforms. Drosophila contains one Notch receptor, $C$. elegans has two redundant receptors, and mammals contain four Notch receptors, Notch1-4. Notch receptors contain an extracellular domain that includes multiple epidermal growth factor (EGF)-like repeats in varying numbers that are involved in ligand binding. The intracellular portion of Notch transmits cellular signals and contains an RBP-Jк Association Module (RAM) domain, a nuclear localization signal (NLS), a seven ankyrin repeat (ANK) domain and a transactivation domain that contains conserved proline/glutamic acid/serine/threonine-rich (PEST) motifs. For a comprehensive review of known Notch ligands, see. ${ }^{[17]}$ In mammals, Notch ligands include Delta-like1 (DLL1), Delta-like3 (DLL3) and Delta-like4 (DLL4), which are homologous to Drosophila Delta, along with Jagged1 (JAG1) and Jagged2 (JAG2), which have homology to Drosophila Serrate. Notch ligands have multiple EGF-like repeats in their extracellular domains and all contain an N-terminal DSL (Delta/Serrate/LAG2) motif that, along with the first two EGF-like repeats is required for ligand-receptor interaction. Jagged ligands contain almost twice the number of EGF repeats as well as an additional cysteine rich region compared to DLL ligands. The intracellular portion of all Notch ligands lacks major homology with the exception that some, but not all, ligands contain multiple lysine residues and a C-terminal PDZ (PSD-95/Dlg/ZO-1) domain.

In addition to the well-studied canonical signaling, Notch signaling can also occur in a non-canonical fashion that is independent of CSL and can be ligand-dependent or independent. ${ }^{[1,20]}$ Compared to canonical Notch signaling, knowledge of non-canonical Notch mechanisms is limited, with the majority of studies performed in cancer and immune system cells. ${ }^{[1]}$ Non-canonical Notch pathways present an interesting new avenue of study and may reveal new targets for therapeutic intervention in the translational setting.

One mechanism of non-canonical Notch signaling occurs through the Wnt/ $\beta$-catenin pathway in cancer and the immune system. The $\mathrm{Wnt} /$-catenin pathway regulates cell pluripotency and cell fate decisions, and aberrant functions or mutations in $\beta$-catenin have been associated with a number of cancers and other human diseases. Noncanonical Notch signaling can result in an antagonistic interaction between Notch signaling and Wnt/ $\beta$ catenin $^{[2,20,21]}$ that disrupts the regulation of developmental and disease processes. ${ }^{[20]}$ This results in an inverse relationship between elevated levels of membrane-bound Notch and lower levels of active $\beta$-catenin ${ }^{[20]}$ leading to negative regulation of Wnt signaling. ${ }^{[4]}$ One example of this crosstalk is the loss of Notch1 in the epidermis of mice, which results in activated Wnt/-catenin signaling and the formation of hyperplasia and cancer -- both of which can be reversed by the introduction of exogenous NICD. ${ }^{[22]}$

Non-canonical Notch signaling is also involved in the activation and proliferation of $\mathrm{CD}^{+} \mathrm{T}$ cells in the immune system as well as in the tumor-promoting effects of interleukin-6 (IL-6). ${ }^{[1,23]}$ These events rely on NF- $\kappa B$ and demonstrate crosstalk with other cellular pathways in the absence of canonical Notch signaling. Studies have demonstrated that even in the absence of CSL, CD4 T-cell activation and proliferation through NF- $\kappa B$ requires NICD playing a major role in the signature CBM complex (CARMA1, MALT1 and BCL10). ${ }^{[2]}$ The NICD can also activate a non-canonical signaling cascade via mTORC2 and Akt as a means of transmitting extracellular nutrient sensing cues to promote cell survival. ${ }^{[5,25]}$ Notch signaling, both canonical and non-canonical, is regulated by a myriad of known and unknown binding partners as well as posttranslational modifications. Comprehensive reviews of Notch signaling are available. ${ }^{[18,26,27]}$

\section{NETS - ENTEROPANCREATIC}

The annual incidence of enteropancreatic NETs is 2-5/100,000 patients in the United States and recent studies suggest that this incidence will continue to rise in the coming years. ${ }^{[21,28-30]}$ Overall survival (OS) for metastatic pancreatic and small bowel NETs is 24 and 56 months, respectively. ${ }^{[29]}$ Enteropancreatic NETs, or NETs that form in the pancreas or the gut (also called carcinoids), can be categorized as functional or non-functional depending on their level of hormone release. Pancreatic NETs can hyper secrete insulin (insulinoma), glucagon (glucagonoma), somatostatin (somatostatinoma), pancreatic polypeptide 
(PPoma) or vasoactive peptide (VIPoma) and those in the GI tract can secrete high levels of gastrin (gastrinoma). The classification of NETs clinically is based on immunohistochemical staining for low molecular weight keratins, chromogranin and somatostatin, as well as an assessment of $\mathrm{Ki}-67$ index from within the region of highest mitotic density. ${ }^{[31]}$ Other observable factors such as anatomical site, histology, grade, level of differentiation and hormone secretion are also used but this phenotypic classification system has led to confusion in both the clinical and research settings due to the molecularly heterogeneous nature of these diseases. For clinical trial purposes, enteropancreatic NETs have historically been grouped together in clinical trials, with enrollment open to all patients with gut NETs regardless of subtype. It is now recognized that NETs must be subdivided into pancreatic and non-pancreatic subgroups to reduce heterogeneity in clinical trials ${ }^{[32]}$ and that progression free survival (PFS) may be a more relevant primary endpoint in clinical trial design than OS because most patients have indolent disease. ${ }^{[33]}$ Additionally, a key predictor of outcome in enteropancreatic NETs is the degree of tumor differentiation. Well-differentiated tumors have a better prognosis than poorly differentiated tumors, which can have a 5 year overall survival of less than $4 \%$. $^{[30]}$

Enteropancreatic NETs are relatively slow-growing and traditional chemotherapy regimens have limited efficacy. ${ }^{[34]}$ The selection of therapy is driven by the staging, location of the tumor and symptom profile. Surgery is often used in the management of NETs for both curative (localized disease) and palliative care (widespread metastases). First line therapy for enteropancreatic NETs is somatostatin analogs (SSAs), ${ }^{[34]}$ with VEGF pathway inhibitors, mTOR inhibitors or peptide receptor radionuclide therapy (PRRT) as additional options. Many of these compounds are currently in clinical practice and/or clinical trials and have exhibited moderate success. SSAs such as octreotide, lanreotide and pasireotide help control symptoms of hormone hypersecretion (carcinoid syndrome), and more recently have been noted to have anti-proliferative effects on well or moderately differentiated NETs. ${ }^{[35,36]}$ For example, the PROMID trial (NCT00171873) examined metastatic midgut $\mathrm{NETs}^{[37]}$ and the CLARINET trial (NCT00353496) focused on pancreatic, midgut or hindgut NETs, ${ }^{[38]}$ both noting prolonged PFS in the SSA treatment arms compared to placebo. The NETTER-1 trial (NCT01578239) uses radiolabeled SSA ([ ${ }^{177} \mathrm{Lu}-\mathrm{DOTA}^{0}$, $\mathrm{Tyr}^{3}$ ] octreotate) in PRRT for a localized anticancer therapy in patients with inoperable, somatostatin receptor positive metastatic midgut NETs with the primary endpoint of PFS. The RADIANT-3 trial (NCT00510068) demonstrated an increased median PFS in patients treated with the mTOR inhibitor everolimus/RAD001 (11 months compared to 4.6 months for placebo) in patients with advanced pancreatic NETs. ${ }^{[39]}$ Finally, the oral tyrosine kinase inhibitor sunitinib was studied in a prospective trial in patients with advanced, well differentiated pancreatic NETs. PFS was
11.6 months in the sunitinib group compared to 5.5 months in the placebo arm. ${ }^{[0]}$ The RADIANT-3 and the sunitinib study both resulted in FDA approval of these drugs for patients with pancreatic NETs. The RADIANT-4 trial (NCT01524783) further confirmed the role of everolimus in adult patients with advanced, progressive, welldifferentiated, non-functional endocrine tumors of the lung or gastrointestinal tract. ${ }^{[41]}$ Patients receiving everolimus had a 7.1 month increase in PFS compared to placebo. ${ }^{[1]}$ A comprehensive review of carcinoid and NET clinical trials is available. ${ }^{[33]}$ The heterogeneity of NETs requires a deeper understanding of tumorigenic mechanisms and drug function that will guide future therapeutic development, patient management strategies and eventually, genomicsdriven clinical trial design.

Genetic syndromes account for $15-20 \%$ of NETs. The most common syndromes include multiple endocrine neoplasia type 1 and type 2A/B (MEN1 and MEN2A/B), von Hippel-Lindau syndrome (VHL), neurofibromatosis type 1 (NF1) and tuberous sclerosis complex (TSC), and in each of these syndromes, specific loss- or gain-of-function mutations have been identified in causative genes. The remaining $80-85 \%$ of NETs is considered sporadic and genome-wide studies have been performed in an attempt to understand driver genetic mutations. Jiao et al. ${ }^{[42]}$ performed whole exome sequencing of 10 pancreatic NETs that resulted in the identification of somatic mutations in a number of known cancer-associated genes including $M E N 1, D A X X, A T R X$, a number of genes involved in the mTOR pathway, and to a lesser extent TP53. Banck et al. ${ }^{[43]}$ studied forty-eight well-differentiated, small intestinal NETs (carcinoids) by whole exome sequencing and also identified somatic mutations in many cancer-associated genes including FGFR2, MEN1, HOOK3, EZH2, MLF1, CARD11, VHL, NONO, SMAD1, FANCD2 and BRAF, yet only 21 genes were in common with a subsequent study that analyzed an additional 55 well-differentiated small intestinal NETs. ${ }^{[44]}$ Upon further comparison with the Jiao study, ${ }^{[42]}$ only 17 genes with somatic mutations found in small intestinal NETs were in common with pancreatic NETs. ${ }^{[44]}$ These data highlight that this group of tumors needs to be carefully studied, subgrouped and analyzed to account for heterogeneity in terms of site of origin, level of differentiation and underlying driver mutations. Interestingly and despite the somewhat disparate results, all of these studies highlight the putative role of chromatin remodeling, perhaps in concert with Notch signaling, in the etiology of enteropancreatic NETs.

A popular model of cancer formation is that tumors are dependent on a subset of highly tumorigenic cells, socalled cancer stem cells, for initiation, maintenance and propagation. ${ }^{[45]}$ Cancer stem cells have been identified in a number of solid tumors ${ }^{[46-48]}$ and leukemias, ${ }^{[49]}$ and are noted for their pluripotency, unique complement of cell-surface antigens, ability to self-renew, and ability to form xenografts in immunocompromised mice from 
very small numbers of cells. Cancer stem cells are often chemoresistant, mediate tumor recurrence, and recruit the host immune system through a variety of mechanisms to support tumor cell growth and metastasis. ${ }^{[45]}$

Cancer stem cells have been identified in gastrointestinal[50] and pancreatic NETs. ${ }^{[1]}$ In gastrointestinal NETs, a population of stem cells was identified based on ALDH positivity which is required for chemoresistance and enhances self-renewal. ${ }^{[50]} \mathrm{ALDH}+$ cells exhibit anchorageindependent growth and have elevated expression of Src, Erk, Akt and mTOR. Because therapies directed towards the Akt/mTOR pathway are already clinically validated in NETs, the investigators focused on Src and treated mouse xenografts with anti-Src siRNA. This treatment resulted in a $91 \%$ decrease in tumor mass and suggested an additional treatment avenue for gastrointestinal NETs. ${ }^{[50]}$ In pancreatic NETs, stem cells have been isolated that co-express the cell-surface protein CD90 and aldehyde dehydrogenase A1 (ALDHA1), as well as CD47 which serves as a flag to evade the immune system. ${ }^{[51]}$ These stem-like cells form tumors in mice and the treatment of tumor-bearing mice with anti-CD47 antibody therapy inhibits tumor growth, prevents metastasis and prolongs survival. Combination therapy with anti-CD47 and anti-EGFR (expressed by the majority of pancreatic NETs) in the preclinical setting demonstrated improved efficacy over anti-CD47 antibody therapy alone ${ }^{[51]}$ and supports the notion that treatment of human pancreatic NETs with stem cell specific antigens will yield clinically significant results.

NETs in general remain significantly understudied with respect to molecular mechanisms of pathogenesis, and particularly Notch signaling. Mechanistically, Notch may contribute to carcinogenesis by inhibiting differentiation, promoting cellular proliferation and/or inhibiting apoptosis, yet few studies have comprehensively examined these endpoints with respect to the four Notch receptors and their ligands in NETs. The available studies suggest a tumor suppressive function for Notch1 in cells derived from the neuroendocrine lineage. This is consistent with role of Notch in Drosophila neurogenesis, where Notch restricts differentiation towards the neuronal lineage. The loss of Notch in Drosophila embryos results in uncontrolled ectodermal differentiation down the neuronal lineage. ${ }^{[52,53]}$ It is plausible that loss of Notch signaling would allow NET cells to acquire or maintain a partially differentiated neuroendocrine phenotype while retaining the ability to proliferate. For example, recent studies ${ }^{[11,12,54-57]}$ report that Notch1 signaling is minimal or absent in gut carcinoids, medullary thyroid carcinoma (MTC) and pulmonary typical and atypical carcinoids. Yet these same cancers express high levels of human achaete-scute homolog 1 (hASH1), a basic helix loop helix transcription factor that is regulated by Notch signaling. The aberrant expression of hASH1 and the arrest of NET cells at an early stage of differentiation may be due to decreased Notch1-activated expression of Hes1 and Hes5 which both facilitate degradation of hASH1. ${ }^{[57]}$ Transient overexpression of NICD in BON1 cells resulted in increased proliferation and dose-dependent increases in Hes1. In contrast, immunohistochemistry for Notch1, Hes1, Hey1, pIGF1R and FGF2 antibodies on a tissue microarray of 120 well differentiated NETs arising from the pancreas $(n=74)$, ileum $(n=31)$ and rectum $(n=15)$, demonstrated elevated Notch 1 expression in $100 \%$ rectal, $34 \%$ of pancreatic, and $0 \%$ of ileal NETs, and Hes 1 expression in $64 \%$ of rectal, $10 \%$ of pancreatic and $0 \%$ of ileal NETs, ${ }^{[58]}$ exhibiting significant variability in Notch1 signaling across different tissue types. There is limited information on other Notch receptors or the ligands involved in Notch signaling in NETs and a comprehensive analysis of Notch expression patterns across all enteropancreatic NET subtypes is required to fully understand the variability and potentially redundant functions of Notch receptors and ligands.

The ability of Notch to behave as an oncogene or tumor suppressor depending on cellular context is driven in part by the availability of coactivators and corepressors. CSL coactivators such as MAML, SKIP and p300 are well known to activate transcription of Notch target genes by binding to NICD. Conversely, in the absence of NICD, corepressors also regulate transcription in specific ways and canonical Notch corepressors include SMRT, ${ }^{[59]}$ SIRT $^{[60]}$ and LSD1 (histone lysine demethylase), ${ }^{[61]}$ among others (reviewed $\mathrm{in}^{[62]}$ ). Epigenetic regulation by Notch activator and repressor complexes containing histone acetyltransferases, histone demethyltransferases, histone methyltransferases, etc. actively remodel the chromatin at Notch-responsive target genes and provide an additional layer of reversible regulation. ${ }^{[63]}$ Chromatin sites accessible to Notch NICDs are also influenced by transcriptional regulators that can act as cofactors or inhibitors. ${ }^{[64-66]}$ A recent report by Liefke et al. ${ }^{[63]}$ demonstrates that the histone demethylase KDM5A/RBP2 is a key component of the CSL repressor complex. Data from our laboratory demonstrates that RBP2 is upregulated in gastrointestinal NETs and in liver metastases from primary NET tumors, suggesting that RBP2 may be actively repressing canonical Notch activity (Crabtree, et al. 2016 Oncogenesis in press).

\section{NETS - PULMONARY}

Pulmonary NETs are an equally diverse set of NETs that fall on a continuum from well-differentiated typical carcinoid (TC), to less differentiated atypical carcinoid (AC), to highly malignant, poorly differentiated small cell lung carcinoma (SCLC) and large cell neuroendocrine carcinoma (LCNECs). ${ }^{[67]}$ Features distinguishing these groups include size, with TC and AC defined as $\geq 0.5 \mathrm{~cm}$, and histologic characteristics such as organoid growth patterns with uniform cytologic features. These tumors contain a moderate amount of eosinophilic cytoplasm and nuclei containing finely granulated chromatin, which is coarser in AC than in TC. Prominent nucleoli are also present in AC, but not in TC. New 2015 WHO 
clinicopathological criteria also define the mitotic index of these tumors (number of mitoses per $2 \mathrm{~mm}^{2}$ in the area of highest mitotic activity with the most viable tumor cells) ${ }^{[68,69]}$ The mitotic index of typical carcinoid is $<2$, atypical carcinoid is 2-10, whereas SCLC and LCNECs have mitotic indices $>10 . .^{[67,68]}$ Lung tumors can also be distinguished by grade, with TC classified as low grade, AC as intermediate grade and SCLC/LCNECs as high grade. ${ }^{[68,69]}$ Identity of these tumors is typically confirmed by immunohistochemistry using the cellular proliferation Ki-67, as well as neuroendocrine markers such as synaptophysin, chromogranin A and neural cell adhesion molecule (NCAM) to distinguish SCLC from non-small cell lung cancer (NSCLC). TC have no necrosis and $\mathrm{Ki}-67 \leq 5 \%, \mathrm{AC}$ can have focal necrosis and $\mathrm{Ki}-67$ $\leq 20 \%$ and SCLC have Ki-67 $>50 \%$. Pulmonary NETs may also exist, albeit at much lower incidence than other pulmonary NETs, as heterogeneous, combination tumors consisting of mixtures of SCLC and LCNEC, or SCLC and NSCLC with neuroendocrine differentiation. ${ }^{[67]}$ These mixed phenotypes may indicate clonal selection and/or phenotypic plasticity of a pluripotent cancer stem cell.

Pulmonary NETs have a low incidence in the US, with a rate of 1.6/100,000 individuals. TCs comprise $1-2 \%$ and ACs make up only $0.1-0.2 \%$ of all pulmonary tumors, whereas SCLC and LCNET make up 20\% and 1.6-3\%, respectively. Overall survival is good for the well-differentiated TC tumors $(92-100 \%$ OS) and moderate for AC (61-88\% OS), whereas the higher grade, poorly differentiated SCLC and LCNET have a grim prognosis with OS as low as $5 \% .{ }^{[70]}$ There are limited treatment options for pulmonary NETs and the only curative therapies for TC and AC is surgery. These tumors are historically refractive to chemotherapy and exhibit response rates as low as $22 \%{ }^{[71]}$ In the case of advanced disease, such as that seen with patients initially presenting with SCLC and LCNEC, surgery is rarely performed and systemic chemotherapy is the first line treatment. Combination etoposide plus carboplatin chemotherapy has high response rates (about 90\%) but within 1 year the majority of tumors recur and are refractory to further treatment. ${ }^{[71]}$ mTORC1 inhibitors (everolimus, temsirolimus) have been used in combination with standard of care chemotherapy, but these compounds exhibited only moderate efficacy with the liability of doselimiting toxicities. ${ }^{[72]}$ mTOR inhibitors have also been combined clinically with SSAs in the RADIANT-2 trial (NCT00412061) that included enteropancreatic NETs as well as pulmonary TC and ACs. Subgroup analyses from this study found a median PFS of 5.6 months for the few TC and AC patients who received only the octreotide LAR and no advantage for the patients receiving the combination therapy ${ }^{[73]} \mathrm{A}$ follow-up trial called the LUNA trial (NCT01563354) is a prospective, randomized, openlabel, three-arm design to study advanced lung (TC and $\mathrm{AC}$ ) and thymic NET response to pasireotide LAR, everolimus or both in combination. The RADIANT-4 trial (NCT01524783) enrolled adult patients with advanced, progressive, well-differentiated, non-functional endocrine tumors of the lung or gastrointestinal tract to receive everolimus or placebo with the primary endpoint of PFS. ${ }^{[41]}$ Patients receiving everolimus had significantly improved median PFS of 7.1 months compared to placebo. ${ }^{[41]}$ Sunitinib was studied in a phase II trial in patients with relapsed or refractory SCLC and the treatment was poorly tolerated and resulted in limited gain in PFS. ${ }^{[74]}$ Tyrosine kinase inhibitors such as imatinib have also been studied in pulmonary NETs with disappointing results..$^{[75]}$

The genetic basis of pulmonary NET formation has been explored in recent years. There are many cases of targeted analysis identifying inactivating mutations in TP53, RB1 and PIK3CA genes. ${ }^{[76-79]}$ Genome-wide studies have been performed ${ }^{[80-83]}$ to identify copy number alterations, somatic single nucleotide variants and alterations in gene expression associated with SCLC. From these studies, potential driver mutations were identified in cancerassociated genes such as TP53, RB1, CREBBP, EP300, $M L L$ and the $S O X$ family. A separate study conducted whole genome sequencing of 110 SCLC and identified biallelic inactivation of TP53, RB1, CREBBP, EP300, $T P 73, R B L 1 / 2$, as well as inactivating mutations in Notch family genes in $25 \%$ of cases. $^{[83,84]}$

As with pancreatic NETs, cancer stem cells provide a plausible mechanism for drug resistance, recurrence and metastasis of SCLC. However, due to limited availability of human clinical samples, the majority of the work to identify markers of SCLC has been performed in cell lines by isolating side populations of cells with stemlike features. Using the SCLC cell lines NCI-H82, H146 and H526, Salcido et al.$^{[85]}$ isolated a population of cells with high rates of proliferation, efficient self-renewal and decreased cell surface expression of CD56 and CD90. These isolated cells also overexpress many genes associated with cancer stem cells and drug resistance, including genes involved in the Notch signaling pathway. ${ }^{[85]}$ In a separate study, a side population of cells was isolated from lung cancer cell lines established from primary tumors. ${ }^{[86]}$ This side population was strongly positive for CD44 and coexpressed CD90, while having mesenchymal morphology, resistance to irradiation, and increased expression of stem cell related genes Nanog and Oct4 ${ }^{[86]} \mathrm{CD} 133$ is a common cell surface antigen in SCLC stem cell populations and was upregulated in cell populations as one of several stem cell markers in six separate studies from various SCLC cell lines. ${ }^{\left[{ }^{[7-92]}\right.}$ In one of these studies, it was found that CD133+ cells express increased neuropeptide receptors which revealed an avenue for therapeutic intervention. ${ }^{[0]}$ Subsequent testing of neuropeptide receptor antagonists revealed that one of the analogs, Peptide 1, decreased cell growth and increased apoptosis in SCLC cell lines. Further, Peptide 1 produced a significant reduction in tumor volume in mouse xenograft models, exhibiting very few CD133 positive cells after treatment, compared with tumors treated with etoposide ${ }^{[90]}$ In other studies, inhibitors 
were selected due to known pathway involvement in SCLC. For example, a dual mTORC1/2 and class I PI3K inhibitor VS-5584 was tested in SCLC xenograft models and a PDX model established from a SCLC lymph node metastasis, resulting in significant decreases in tumor burden, decreased tumor-initiating frequency and marked depletion of cancer stem cells. ${ }^{[93]}$

The Notch signaling pathway is of increasing interest in SCLC and as with enteropancreatic NETs, Notch signaling in the lung is tissue type and cell context dependent. Notch signaling can promote the growth of NSCLC, yet inhibit the growth of SCLC. ${ }^{[94,95]}$ The tumor phenotype in SCLC may be driven via Notch3 expression, which is decreased in SCLC compared to non-tumor lung tissue as measured by immunohistochemistry. ${ }^{[96]}$ SCLC may be the result of deregulated Notch in cell fate decisions that determine differentiation towards the epithelial Clara, ciliated and pulmonary neuroendocrine cell lineages. ${ }^{[97]}$ In mouse models with allelic series deletion of Notch1, 2 and 3, all three Notch receptors were required in an additive manner to regulate the abundance of neuroendocrine cells in the lung, whereas only contribution from Notch 2 was required for Clara/ciliated cell development. ${ }^{[98]}$

Over the years, many targeted therapies have been developed to modulate the Notch signaling pathway, including neutralizing antibodies, decoy ligands, blocking peptides, natural compounds and -secretase inhibitors (reviewed in ${ }^{[18]}$ ). The Notch $2 / 3$ neutralizing antibody tarextumab, inhibits tumor growth in mice in a variety of epithelial tumors, but also in SCLC xenograft tumors, ${ }^{[99]}$ suggesting that Notch2 and/or Notch3 inhibition can be therapeutic in the clinical setting. A novel way of exploiting decreased Notch signaling therapeutically is by targeting Notch ligands that are frequently overexpressed even in tumors with low or absent canonical Notch signaling. This approach was pioneered in SCLC, which frequently expresses high levels of DLL3. Because DLL3 can function as a Notch inhibitor by retaining Notch receptors in the cytoplasm or by cis-inhibition, a DLL3 $\mathrm{mAb}$ conjugated with a DNA damaging toxin was used as a highly effective chemotherapeutic in preclinical PDX models of SCLC. These experiments resulted in complete, durable responses 5 months post treatment. The naked $\mathrm{mAb}$ had no therapeutic activity, suggesting that DLL3 inhibition alone is not sufficient for tumor regression in SCLC . ${ }^{[14]}$ In other studies, it has been proposed that, in addition to the primary SCLC progression as a result of TP53 and RB1 alterations, secondary transitions from nonsmall cell lung carcinoma to SCLC can occur following chemotherapy. This implies phenotypic plasticity from an epithelial to a neuroendocrine lineage can occur under treatment-imposed selection. A recent publication by Meder et al. $^{[13]}$ demonstrates that this process is mediated by the Notch-ASCL1-RB-P53 signaling axis.

Paralog-specific effects add yet another layer of complexity to Notch signaling, since not all Notch receptors are created equal. Notch receptors are not always redundant and in some cases their functions are not only independent but opposite. Notch1 and Notch2 have opposite effects on Akt in NSCLC. ${ }^{[100]}$ In Luminal B breast cancer, Notch1 and Notch4 have similar effects on endocrine resistance but act through completely different sets of downstream genes and produce different cellular phenotypes ${ }^{[101]}$ (Espinoza and Miele, unpublished). Notch1, 3, and 4 are oncogenic in the breast, while Notch2 has been described as a tumor suppressor in breast cancer cell lines. ${ }^{[102]}$ The mechanism of these paralog-specific effects is unknown but may involve non-canonical signals, such as the inhibitory role of Notch4 on SMAD ${ }^{[103]}$ or the stimulatory role of Notch1 on NF- $\kappa B .{ }^{[104]}$ The oncogenic activity of Notch4 in the mouse mammary gland is independent of CSL and is therefore completely or at least partially non-canonical. ${ }^{[105]}$ Another explanation for paralog-specific effects may be in quantitative signal intensity of the different Notch ligands. For example, constitutively activating mutations in Notch 1 and Notch2 are equally oncogenic in a subset of triple negative breast cancer (TNBC), ${ }^{[106]}$ despite the fact that Notch2 has been described as a tumor suppressor in TNBC cell lines. ${ }^{[102]}$ Therefore, the absolute number of NICD molecules available as a result of overproduction or decreased turnover may dictate different phenotypic consequences. Additionally, paralog-specific effects may also be achieved by selective activation of chromatin sites with different affinity for Notch NICDs, epigenetic modifications by NICD binding partners that alters binding site availability, or by a combination of canonical and non-canonical effects that depends on NICD abundance. In short, the role of paralog-specific effects has been poorly characterized in NETs and is an area in need of further study.

\section{NETs - SKIN}

Merkel cell carcinoma (MCC) is a rare, aggressive cutaneous NET that occurs most frequently in the elderly and/or the immunosuppressed, although more than $90 \%$ of MCC patients have no known immune dysfunction. ${ }^{[107]}$ It is seen primarily in light-skinned individuals and has a male predominance of 2:1. ${ }^{[108]} \mathrm{MCC}$ occurs most frequently in sun-exposed areas of skin, particularly the head and neck, followed by extremities and then the trunk. In $80 \%$ of cases, MCC is associated with the Merkel cell polyomavirus (MCPyV). ${ }^{[109,110]}$ Infection with MCPyV is not sufficient to induce tumorigenesis ${ }^{[111]}$ and additional events including loss of cellular immune surveillance are required for oncogenic transformation. The MCPyV large T-antigen is oncogenic in MCC by binding the retinoblastoma protein and promoting cell cycle progression. ${ }^{[112]}$ The small T-antigen of MCPyV acts downstream of the mTOR signaling pathway by maintaining hyperphosphorylation of 4E-binding protein (4EBP1), resulting in dysregulated cap-dependent translation in MCC. ${ }^{[113]}$ Patients with MCPyV negative MCC tumors have increased DNA 
damage signatures at the genetic level, presumably as a result of UV exposure. ${ }^{[114,115]}$

MCC is highly metastatic and the 5 year survival rate is dependent on the stage at which original diagnosis is made. Patients with local disease at diagnosis have a 5 year OS of $63-87 \%$, those with regional nodal involvement $39-42 \%$ and $0-18 \%$ for patients with widespread, distant metastases. ${ }^{[116]}$ The annual incidence of MCC in the US is increasing, with an estimated 1,600 patients diagnosed per year. ${ }^{[117]}$ The increase in incidence is attributed to population aging, more known risk factors associated with this cancer (such as increased aggregate sun exposure), and increased diagnostic power with cytokeratin 20 immunohistochemical staining, which is positive in 88$100 \%$ of MCC cases. ${ }^{[118]}$

There are no FDA-approved agents for the treatment of MCC, nor are there established, standard of care chemotherapy regimens. ${ }^{[109]}$ Current first line therapies for localized disease include surgical resection followed by postoperative radiation therapy. Radiotherapy plays a significant role in both the curative setting, and palliative care setting when used as a monotherapy in advanced metastatic MCC. ${ }^{[119]}$ Systemic chemotherapy regimens used for SCLC are employed and typically include a combination of a platinum agent (cisplatin or carboplatin) and topoisomerase inhibitor (etoposide) ${ }^{[120-122]}$ or combination cyclophosphamide, doxorubicin and vincristine therapy (CAV therapy). ${ }^{[122]}$ Cytotoxic chemotherapies do not produce durable responses and are associated with significant toxicity, highlighting the need for targeted, mechanism-based therapies. Immunohistochemical analysis of MCC tumors has led to development and use of several new mechanism-based therapies including SSAs (octreotide, lanreotide), ${ }^{[123,124]}$ pan-receptor tyrosine kinase inhibitors (pazopanib), ${ }^{[125]}$ PI3K inhibitors, ${ }^{[126,127]}$ vitamin D receptor agonists, ${ }^{[128]}$ small molecules to downregulate Survivin, ${ }^{[129,130]}$ antiPD-L1 antibody therapy, ${ }^{[131]}$ and an antibody conjugate linking a maytansinoid microtubule assembly inhibitor to CD56 (lorvotuzumab mertansine). ${ }^{[132]}$ Many of these are now in clinical trials for MCC and an excellent review of future potential therapeutic options and current clinical trials for MCC can be found in ref. ${ }^{[118]}$

In addition to immunohistochemistry, genomic studies have also been applied to MCC to identify new therapeutic targets and understand the mechanism of tumorigenesis in both MCPyV positive and negative cases. Gene panel studies on $15 \mathrm{MCPyV}$ negative and $12 \mathrm{MCPyV}$ positive MCC samples identified mutations in TP53, KIT, PIK3CA and EGFR genes, with RBI mutations only identified in the virus negative samples, suggesting that the dysregulation of the RB pathway may be a critical step in tumorigenesis. ${ }^{[133]}$ Targeted sequencing of 17 MCC patient samples with unknown virus status, identified mutations in TP53, RB and NOTCH1, among others. ${ }^{[134]}$
Exome sequencing studies performed on small numbers of formalin-fixed, paraffin-embedded MCC samples and also identified $R B 1$ in $\mathrm{MCPyV}$ negative tumors. ${ }^{[135]}$ Another small study conducted on $4 \mathrm{MCPyV}$ positive tumors identified somatic mutations in PDE4DIP, as well as genes within the DNA damage response (PRKDC, AURKB, ERCC5, ATR and ATRX) and epigenetic modifying enzymes (MLL3). ${ }^{[136]}$ Harms et al. ${ }^{[115]}$ performed a slightly larger study of whole exome sequencing of $9 \mathrm{MCPyV}$ negative and $7 \mathrm{MCPyV}$ positive MCC samples. Known mutations were identified in TP53, RB1 and PIK3CA along with novel activating mutations in oncogenes like $H R A S$, loss-of-function mutations in PRUNE2 and NOTCH family genes, and mutations disrupting the PI3K signaling pathway in the MCPyV negative tumors. ${ }^{[115,137]}$ Further, the MCPyV negative tumors also had a higher overall mutational burden and were characterized by a prominent UV-signature pattern with $\mathrm{C}>\mathrm{T}$ transitions making up $85 \%$ of the mutations. MCPyV positive tumors had a much lower mutational burden and were lacking the UV signature, suggesting that MCPyV negative tumors have increased susceptibility to UV damage. ${ }^{[115]}$ The most comprehensive study to date included exome sequencing of 49 MCC samples (21 positive, 27 negative). ${ }^{[114]}$ This study confirmed the previous report that the signature of $\mathrm{MCPyV}$ negative tumors is very different than the MCPyV positive tumors. MCPyV negative tumors have a higher mutation burden, frequent mutations in TP53 and RBI and additional mutations in genes involved in chromatin modification ( $A S X L 1, M L L 2$ and $M L L 3)$ and DNA damage pathways (ATM, MSH2, BRCA1). Interestingly, both MCPyV positive and negative tumors have mutations predicted to activate the PI3K pathway (HRAS, KRAS, PIK3CA, PTEN and TSC1) and to inactivate the Notch signaling pathway (Notch1, Notch2), ${ }^{[114]}$ suggesting these pathways as putative points for intervention in $\mathrm{MCC}$ regardless of viral status.

As discussed for SCLC and enteropancreatic NETs, another possible point of intervention is by targeting cancer stem cells. However, in the case of MCC, the cell of origin is still under debate. Based on early observation of MCC and the similarity of expression patterns for neuroendocrine and epithelial markers, it was presumed that MCCs arise from the Merkel cell, part of the somatosensory system located within the basal epidermis. However, with the observations that Merkel cells and MCC are found in different regions of the skin and exhibit differential expression of marker proteins, new data are challenging the concept that MCCs arise from Merkel cells. ${ }^{[138]}$ One theory, based on pathologic diagnosis of MCC suggests a role for pluripotent stem cells in the dermis as the cells of origin, facilitated by UV irradiation and $\mathrm{MCPyV}$ infection. ${ }^{[139]}$ Another study proposes that MCCs arise from pro/pre-B or pre-B cells based on terminal deoxynucleotidyl transferase and PAX5 expression, as well as the preference for polyomaviruses to preferentially infect undifferentiated stem cells or progenitor cells. ${ }^{[140]}$ However, in the absence 
of experimental evidence supporting a stem cell origin, more lineage tracking studies are needed to identify the cellular origin of MCC.

Notch signaling has been an area of active investigation in MCC as a result of the genome-wide studies that have highlighted the Notch pathway as one of key interest, with somatic single nucleotide variants identified in Notch1, and Notch2 that were independent MCPyV status. ${ }^{[114]}$ The inactivating mutations detected in Notch genes were located in the EGF-like and ankyrin repeat regions, consistent with loss-of-function events characterizing a tumor suppressive role for Notch in MCC. ${ }^{[115]}$ Further, the data on Notch and other genes dysregulated in MCC are common with SCLC, suggesting that these pathways are also cornerstones of neuroendocrine differentiation in epithelial cells. ${ }^{[114]}$ Another study examined the Notch signaling pathway as a target of microRNA-375, which is highly overexpressed in well-differentiated MCC cell lines yet strikingly downregulated in highly aggressive, undifferentiated MCC cell lines. ${ }^{[141]}$ miR-375 overexpression caused posttranscriptional repression of Notch2 and RBPJ resulting in decreased cell proliferation, migration and invasion in vitro. This led to the conclusion that miR-375 is a putative regulator of cancer cell aggressiveness through inhibition of Notch signaling. ${ }^{[141]}$ In contrast, Panelos et $a l .{ }^{[142]}$ performed immunohistochemical studies of Notch1 expression in MCC and found 30/31 cases had Notch1 cytoplasmic and membrane expression in greater than $50 \%$ of cells. These data contradict the data in other NETs, including other data on MCC, which suggest Notch1 is a tumor suppressor in MCCs.

\section{NETs - THYROID}

Medullary thyroid carcinoma (MTC) is a NET that originates from the thyroid C-cells and express high levels of calcitonin, chromogranin A, synaptophysin and achaete-scute complex-like 1 (ASCL1). MTCs are relatively slow growing tumors that comprise $1-2 \%$ of all thyroid cancers and have a 10 year median survival of $65 \%{ }^{[143,144]}$ The majority of these tumors are sporadic, but they can be hereditary and arise with other NETs as a part of MEN2A/2B or as familial MTC. Gain-offunction mutations in the RET tyrosine kinase gene (most commonly M918T) are the known driver mutation in the majority of these tumors. ${ }^{[145,146]}$ Those tumors that are RET mutation negative frequently have RAS mutations - and the presence of these mutations appears mutually exclusive. ${ }^{[147,148]}$ As with other NETs discussed above, there are no curative therapies for MTC. Surgery is the first line of treatment for localized disease, but there are no therapeutic options for patients who present with regional or widespread metastases, highlighting the critical need for additional therapeutics.

Several promising new directed therapies for MTC are in development or clinical trials. As with other NETs, SSAs and mTOR inhibitors have been studied in MTC, and have shown preliminary efficacy in small trials. ${ }^{[149,150]}$ One ongoing trial (NCT01625520) is examining the efficacy of SOM230/pasireotide alone and in combination with everolimus in progressive metastatic or postoperative persistent MTC. More recently, new drugs that targets both PI3K and mTOR have been developed, with BEZ235 showing efficacy in preclinical studies of thyroid cancer. ${ }^{[151]}$ Antibody therapy is also in development for MTC. Carcinoembryonic antigen or CEA is an antigen expressed by MTC cells and an anti-CEA monoclonal antibody combined with autologous hematopoietic stem cell rescue has shown promise in a phase 1 study in rapidly progressing metastatic MTC. ${ }^{[152]}$

Tyrosine kinase inhibitors are also in development and AMG706/motesanib was studied in locally advanced or metastatic, progressive or symptomatic MTC in a singlearm phase 2 study. ${ }^{[153]}$ Despite the $81 \%$ of patients in this trial that achieved stable disease, there was no placebo or standard of care arm, making the interpretation of drug efficacy and toxicity a challenge. Axitinib was also studied in a small trial of locally advanced MTC $(n=6)$, and resulted in $5 / 6$ or $83 \%$ of patients with stable disease $>16$ weeks. ${ }^{[154]}$ However, as with the motesanib trial, the single-arm study design, as well as the small number of MTC patients included makes the trial results difficult to interpret. The ZETA and EXAM trials studied two additional compounds, vandetanib and cabozantinib, in advanced, unresectable, locally advanced or metastatic MTC. The first randomized, double-blind, placebo controlled study (ZETA trial; NCT 00410761) tested vandetanib and detected an increase in PFS (30.5 vs. 19.3 months for placebo) in the 331 patients recruited to the study. Stratification of the patients by RET mutation suggested that there was an improved response in patients with RET M918T mutation and also in MTC cases with no RET mutation identified. ${ }^{[155]}$ These data led to FDA and EMA approval for vandetanib for the treatment of symptomatic or progressive, unresectable, locally advanced or metastatic MTC. The EXAM trial (NCT00704730) was a randomized, double-blind, placebo controlled study of cabozantinib in advanced and progressive MTC. This study recruited 330 patients and reported a median PFS of 11.2 months for treatment versus 4.0 months in controls. ${ }^{[156]}$ The responses in this trial were similar regardless of RET mutational status, and the results from this trial led to FDA and EMA approval of cabozantinib for progressive, metastatic MTC. Another tyrosine kinase inhibitor, regorafenib which has been approved for treatment of metastatic colorectal cancer, is now being studied as a second or third line therapy in MTC (NCT02657551). For recent, more comprehensive reviews of new molecular therapies and thyroid cancer clinical trials including those for MTC, see. ${ }^{[143,157]}$

Although the genetic gain-of-function RET mutations are well established as the basis for MTC, additional genetic studies have been performed to understand the etiology of 
RET mutation negative MTCs, and endocrine syndromerelated MTCs. Exome sequencing of 17 sporadic MTCs identified the expected mutually exclusive RAS and RET mutations, but no other commonly occurring driver mutations. ${ }^{[148]}$ Exome sequencing of MTCs associated with MEN2A also identified the expected RET mutations, but also suggested that low frequency mutations such as those found in EIF4G1 may also play a role in MEN2Aassociated tumorigenesis by indirectly altering the RET pathway. ${ }^{[158]}$ A similar study was undertaken by Smith et al.$^{[159]}$ in MTCs lacking an identifiable RET mutation. Interestingly, this group found a recurrent mutation in the ESR2 gene which encodes the estrogen receptor beta (ER). Estrogen receptor alpha (ER) and ER can form heterodimers and bind to estrogen response elements to regulate gene expression. ${ }^{[160]}$ Alternatively, ER can antagonize the transcriptional activity of ER. ${ }^{[161-163]}$ The RET gene contains three ERE sites that were shown to be actively regulating RET gene expression in vitro. The authors propose that this may be a novel mechanism by which the RET gene is regulated in RET mutation-negative familial MTC. ${ }^{[159]}$ Heilmann et al. ${ }^{[164]}$ performed genomic profiling of MTC cases during the course of clinical care and in addition to the expected RET mutations, also identified amplifications of CCND1, FGF3, FGF19 and CDKN2A. The authors propose that these may be cooperating driver mutations impacting chemoresistance and disease outcomes.

Cancer stem cells have been identified in MTC cell lines that are strongly positive for the cell surface antigen CD133 by immunohistochemistry. ${ }^{[165]}$ Interestingly, cell lines with the M918T RET mutation produce the highest number of $\mathrm{CD}_{133^{+}}$stem-like cells. ${ }^{[165]}$ This population of stem-like cells may also be involved in chemoresistance. In a study by Kucerova, CD133 ${ }^{+}$cells from MTC cell lines were no more chemoresistant than the parent population of cells. However, once the $\mathrm{CD} 133^{+}$cells were implanted in mice as xenografts and treated with 5-fluorouracil (5-FU), there emerged a new $\mathrm{CD} 133^{+}$stem-like cell population that was resistant to subsequent 5-FU therapy and retained these chemoresistant properties in culture. ${ }^{[166]}$ MTCs are relatively resistant to the radioactive iodine therapies used for follicular and poorly differentiated thyroid cancers, and one group treated MTC stem cells with all-transretinoic acid (ATRA) to sensitize these cells to radioiodine therapy. The stem cells identified and treated with ATRA increased their uptake of iodine by 8 fold, suggesting that ATRA pre-treatment followed by radioactive iodine therapy may be a new treatment modality for MTC. ${ }^{[167]}$ Finally, co-expression of CD133 and CD44 in MTC by immunohistochemistry was correlated with decreased overall survival in a cohort of 51 MTC patients, compared to those with no co-expression of these two markers implying that CD133 and CD44 can be used as prognostic markers for overall survival. ${ }^{[168]}$

At the molecular level, MTC cells express a variety of proteins including calcitonin and chromogranin $\mathrm{A}$, as well as ASCL1 (also important in pulmonary NETs). Notch is one of the pathways regulating the production of ASCL1, especially during development. Notch1 expression is absent in MTC and overexpression of the Notch intracellular domain decreases proliferation of MTC cell lines, ${ }^{[5]}$ consistent with its role as a tumor suppressor. Activation of Notch in MTC by pharmaceutical means became possible when valproic acid was reported to activate Notch in neuroblastoma cells ${ }^{[169]}$ and subsequent work demonstrated that valproic acid increased Notch1 signaling and induced apoptosis in MTC cells. ${ }^{[170]}$ Using a mouse model system, Jaskula-Sztul et al. ${ }^{[171]}$ demonstrated that activation of the Notch signaling pathway may be a therapeutic strategy for MTC. This same group expanded our knowledge of Notch signaling in MTC by upregulating Notch3 in vitro and in vivo via NICD3 and the pharmacological HDAC inhibitor ABA3. They demonstrated that Notch3, like Notch1, can alter the neuroendocrine phenotype in MTC, resulting in decreased proliferation and loss of NET markers. ${ }^{[172]}$ Resveratrol treatment of MTC cells suppresses growth, induces apoptosis and reduces expression of chromogranin A and ASCL1 as a result of upregulation of Notch2. ${ }^{[173]}$ In similar studies, thiocoraline treatment in vitro increases the expression of Notch1 and Notch2 isoforms, as well as the downstream Notch target genes HES1, HES2 and HEY1, while expression of HES6 decreased. ${ }^{[174]}$ Taken together, these studies indicate a clear role for Notch signaling in MTC therapy.

\section{CONCLUSION}

The role of Notch signaling in NETs remains incompletely understood. Further study is required to understand how this pathway impacts tumorigenesis and chemoresistance in this diverse tumor group. There is evidence that different Notch isoforms act as tumor suppressors in some NETs but not others and paralog specific effects are understudied and remain unclear. The significant genetic heterogeneity of NETs suggests that individual molecular subtypes must be studied separately to dissect the roles of Notch signaling components and their potential therapeutic implications.

\section{Financial support and sponsorship}

This work was supported by the Louisiana State University Health Science Center School of Medicine, Department of Genetics.

\section{Conflicts of interest}

There are no conflicts of interest.

\section{REFERENCES}

1. Ayaz F, Osborne BA. Non-canonical notch signaling in cancer and immunity. Front Oncol 2014;4:345.

2. Collu GM, Hidalgo-Sastre A, Brennan K. Wnt-Notch signalling crosstalk in development and disease. Cell Mol Life Sci 2014;71:3553-67.

3. Jin S, Mutvei AP, Chivukula IV, Andersson ER, Ramskold D, Sandberg R, Lee KL, Kronqvist P, Mamaeva V, Ostling P, Mpindi 
JP, Kallioniemi O, Screpanti I, Poellinger L, Sahlgren C, Lendahl U. Non-canonical Notch signaling activates IL-6/JAK/STAT signaling in breast tumor cells and is controlled by p53 and IKKalpha/ IKKbeta. Oncogene 2013;32:4892-902.

4. Kwon C, Cheng P, King IN, Andersen P, Shenje L, Nigam V, Srivastava D. Notch post-translationally regulates beta-catenin protein in stem and progenitor cells. Nat Cell Biol 2011;13:1244-51.

5. Perumalsamy LR, Nagala M, Banerjee P, Sarin A. A hierarchical cascade activated by non-canonical Notch signaling and the mTORRictor complex regulates neglect-induced death in mammalian cells. Cell Death Differ 2009;16:879-89.

6. Shin HM, Tilahun ME, Cho OH, Chandiran K, Kuksin CA, Keerthivasan S, Fauq AH, Golde TE, Miele L, Thome M, Osborne BA, Minter LM. NOTCH1 can initiate NF-kappaB activation via cytosolic interactions with components of the T cell signalosome. Front Immunol 2014;5:249.

7. Bocchetta M, Miele L, Pass HI, Carbone M. Notch-1 induction, a novel activity of SV40 required for growth of SV40-transformed human mesothelial cells. Oncogene 2003;22:81-9.

8. Carter Y, Jaskula-Sztul R, Chen H, Mazeh H. Signaling pathways as specific pharmacologic targets for neuroendocrine tumor therapy: RET, PI3K, MEK, growth factors, and Notch. Neuroendocrinology 2013;97:57-66.

9. Hassan WA, Yoshida R, Kudoh S, Hasegawa K, Niimori-Kita K, Ito T. Notch1 controls cell invasion and metastasis in small cell lung carcinoma cell lines. Lung Cancer 2014;86:304-10.

10. Krausch M, Kroepil F, Lehwald N, Lachenmayer A, Schott M, Anlauf M, Cupisti K, Knoefel WT, Raffel A. Notch 1 tumor expression is lacking in highly proliferative pancreatic neuroendocrine tumors. Endocrine 2013;44:182-6.

11. Kunnimalaiyaan $\mathrm{M}$, Chen $\mathrm{H}$. Tumor suppressor role of Notch-1 signaling in neuroendocrine tumors. Oncologist 2007;12:535-42.

12. Kunnimalaiyaan M, Yan S, Wong F, Zhang YW, Chen H. Hairy Enhancer of Split-1 (HES-1), a Notch1 effector, inhibits the growth of carcinoid tumor cells. Surgery 2005;138:1137-42; discussion 42.

13. Meder L, Konig K, Ozretic L, Schultheis AM, Ueckeroth F, Ade CP, Albus K, Boehm D, Rommerscheidt-Fuss U, Florin A, Buhl T, Hartmann W, Wolf J, Merkelbach-Bruse S, Eilers M, Perner S, Heukamp LC, Buettner R. NOTCH, ASCL1, p53 and RB alterations define an alternative pathway driving neuroendocrine and small cell lung carcinomas. Int $J$ Cancer 2016;138:927-38.

14. Saunders LR, Bankovich AJ, Anderson WC, Aujay MA, Bheddah S, Black K, Desai R, Escarpe PA, Hampl J, Laysang A, Liu D, Lopez-Molina J, Milton M, Park A, Pysz MA, Shao H, Slingerland B, Torgov M, Williams SA, Foord O, Howard P, Jassem J, Badzio A, Czapiewski P, Harpole DH, Dowlati A, Massion PP, Travis WD, Pietanza MC, Poirier JT, Rudin CM, Stull RA, Dylla SJ. A DLL3targeted antibody-drug conjugate eradicates high-grade pulmonary neuroendocrine tumor-initiating cells in vivo. Sci Transl Med 2015;7:302ra136.

15. Andersson ER, Lendahl U. Therapeutic modulation of Notch signalling -- are we there yet? Nat Rev Drug Discov 2014;13:357-78.

16. Chikara S, Reindl KM. Notch signaling: a hero or villain in the war against cancer? Transl Lung Cancer Res 2013;2:449-51.

17. D'Souza B, Miyamoto A, Weinmaster G. The many facets of Notch ligands. Oncogene 2008;27:5148-67.

18. Espinoza I, Miele L. Notch inhibitors for cancer treatment. Pharmacol Ther 2013;139:95-110.

19. Hirata N, Yamada S, Shoda T, Kurihara M, Sekino Y, Kanda Y. Sphingosine-1-phosphate promotes expansion of cancer stem cells via S1PR3 by a ligand-independent Notch activation. Nat Commun 2014;5:4806

20. Andersen P, Uosaki H, Shenje LT, Kwon C. Non-canonical Notch signaling: emerging role and mechanism. Trends Cell Biol 2012;22:257-65.

21. Lawrence B, Gustafsson BI, Chan A, Svejda B, Kidd M, Modlin
IM. The epidemiology of gastroenteropancreatic neuroendocrine tumors. Endocrinol Metab Clin North Am 2011;40:1-18, vii.

22. Nicolas M, Wolfer A, Raj K, Kummer JA, Mill P, van Noort M, Hui CC, Clevers H, Dotto GP, Radtke F. Notch1 functions as a tumor suppressor in mouse skin. Nat Genet 2003;33:416-21

23. Dongre A, Surampudi L, Lawlor RG, Fauq AH, Miele L, Golde TE, Minter LM, Osborne BA. Non-Canonical Notch Signaling Drives Activation and Differentiation of Peripheral CD4(+) T Cells. Front Immunol 2014;5:54.

24. Minter LM, Osborne BA. Canonical and non-canonical Notch signaling in CD4(+) T cells. Curr Top Microbiol Immunol 2012;360:99-114.

25. Meurette O, Stylianou S, Rock R, Collu GM, Gilmore AP, Brennan $\mathrm{K}$. Notch activation induces Akt signaling via an autocrine loop to prevent apoptosis in breast epithelial cells. Cancer Res 2009;69:5015-22.

26. Crabtree JS, Singleton CS, Miele L. Notch Signaling in Neuroendocrine Tumors. Front Oncol 2016;6:94.

27. Borggrefe T, Oswald F. The Notch signaling pathway: transcriptional regulation at Notch target genes. Cell Mol Life Sci 2009;66:1631-46.

28. Garcia-Carbonero R, Capdevila J, Crespo-Herrero G, Diaz-Perez JA, Martinez Del Prado MP, Alonso Orduna V, Sevilla-Garcia I, Villabona-Artero C, Beguiristain-Gomez A, Llanos-Munoz M, Marazuela M, Alvarez-Escola C, Castellano D, Vilar E, JimenezFonseca P, Teule A, Sastre-Valera J, Benavent-Vinuelas M, Monleon A, Salazar R. Incidence, patterns of care and prognostic factors for outcome of gastroenteropancreatic neuroendocrine tumors (GEP-NETs): results from the National Cancer Registry of Spain (RGETNE). Ann Oncol 2010;21:1794-803.

29. Mocellin S, Nitti D. Gastrointestinal carcinoid: epidemiological and survival evidence from a large population-based study $(\mathrm{n}=25531)$. Ann Oncol 2013;24:3040-4.

30. Yao JC, Hassan M, Phan A, Dagohoy C, Leary C, Mares JE, Abdalla EK, Fleming JB, Vauthey JN, Rashid A, Evans DB. One hundred years after "carcinoid": epidemiology of and prognostic factors for neuroendocrine tumors in 35,825 cases in the United States. J Clin Oncol 2008;26:3063-72.

31. Klimstra DS, Modlin IR, Adsay NV, Chetty R, Deshpande V, Gonen M, Jensen RT, Kidd M, Kulke MH, Lloyd RV, Moran C, Moss SF, Oberg K, O'Toole D, Rindi G, Robert ME, Suster S, Tang LH, Tzen CY, Washington MK, Wiedenmann B, Yao J. Pathology reporting of neuroendocrine tumors: application of the Delphic consensus process to the development of a minimum pathology data set. Am J Surg Pathol 2010;34:300-13.

32. Strosberg J. Neuroendocrine tumours of the small intestine. Best Pract Res Clin Gastroenterol 2012;26:755-73.

33. Kunz PL. Carcinoid and Neuroendocrine Tumors: Building on Success. J Clin Oncol 2015;33:1855-63.

34. National Comprehensive Cancer Network. NCCN clinical practice guidelines in oncology: neuroendocrine tumors v, 2016. Updated 5/25/2016, accessed 7/28/16. In.

35. Susini C, Buscail L. Rationale for the use of somatostatin analogs as antitumor agents. Ann Oncol 2006;17:1733-42.

36. Cives M, Strosberg J. The expanding role of somatostatin analogs in gastroenteropancreatic and lung neuroendocrine tumors. Drugs 2015; 75:847-58.

37. Rinke A, Muller HH, Schade-Brittinger C, Klose KJ, Barth P, Wied M, Mayer C, Aminossadati B, Pape UF, Blaker M, Harder J, Arnold C, Gress T, Arnold R, Group PS. Placebo-controlled, double-blind, prospective, randomized study on the effect of octreotide LAR in the control of tumor growth in patients with metastatic neuroendocrine midgut tumors: a report from the PROMID Study Group. $J$ Clin Oncol 2009;27:4656-63.

38. Caplin ME, Pavel M, Cwikla JB, Phan AT, Raderer M, Sedlackova E, Cadiot G, Wolin EM, Capdevila J, Wall L, Rindi G, Langley A, Martinez S, Blumberg J, Ruszniewski P, Investigators C. Lanreotide in metastatic enteropancreatic neuroendocrine tumors. $N$ Engl $J$ 
Med 2014;371:224-33

39. Yao JC, Shah MH, Ito T, Bohas CL, Wolin EM, Van Cutsem E, Hobday TJ, Okusaka T, Capdevila J, de Vries EG, Tomassetti P, Pavel ME, Hoosen S, Haas T, Lincy J, Lebwohl D, Oberg K, Rad001 in Advanced Neuroendocrine Tumors TTSG. Everolimus for advanced pancreatic neuroendocrine tumors. $N$ Engl $\mathrm{J} \mathrm{Med}$ 2011;364:514-23.

40. Raymond E, Dahan L, Raoul JL, Bang YJ, Borbath I, LombardBohas C, Valle J, Metrakos P, Smith D, Vinik A, Chen JS, Horsch D, Hammel P, Wiedenmann B, Van Cutsem E, Patyna S, Lu DR, Blanckmeister C, Chao R, Ruszniewski P. Sunitinib malate for the treatment of pancreatic neuroendocrine tumors. $N$ Engl J Med 2011;364:501-13.

41. Yao JC, Fazio N, Singh S, Buzzoni R, Carnaghi C, Wolin E, Tomasek J, Raderer M, Lahner H, Voi M, Pacaud LB, Rouyrre N, Sachs C, Valle JW, Delle Fave G, Van Cutsem E, Tesselaar M, Shimada Y, Oh DY, Strosberg J, Kulke MH, Pavel ME, Rad001 in Advanced Neuroendocrine Tumours FTSG. Everolimus for the treatment of advanced, non-functional neuroendocrine tumours of the lung or gastrointestinal tract (RADIANT-4): a randomised, placebo-controlled, phase 3 study. Lancet 2016;387:968-77.

42. Jiao Y, Shi C, Edil BH, de Wilde RF, Klimstra DS, Maitra A, Schulick RD, Tang LH, Wolfgang CL, Choti MA, Velculescu VE, Diaz LA, Jr., Vogelstein B, Kinzler KW, Hruban RH, Papadopoulos N. DAXX/ATRX, MEN1, and mTOR pathway genes are frequently altered in pancreatic neuroendocrine tumors. Science 2011;331:1199-203.

43. Banck MS, Kanwar R, Kulkarni AA, Boora GK, Metge F, Kipp BR, Zhang L, Thorland EC, Minn KT, Tentu R, Eckloff BW, Wieben ED, Wu Y, Cunningham JM, Nagorney DM, Gilbert JA, Ames MM, Beutler AS. The genomic landscape of small intestine neuroendocrine tumors. J Clin Invest 2013;123:2502-8.

44. Francis JM, Kiezun A, Ramos AH, Serra S, Pedamallu CS, Qian ZR, Banck MS, Kanwar R, Kulkarni AA, Karpathakis A, Manzo V, Contractor T, Philips J, Nickerson E, Pho N, Hooshmand SM, Brais LK, Lawrence MS, Pugh T, McKenna A, Sivachenko A, Cibulskis K, Carter SL, Ojesina AI, Freeman S, Jones RT, Voet D, Saksena G, Auclair D, Onofrio R, Shefler E, Sougnez C, Grimsby J, Green L, Lennon N, Meyer T, Caplin M, Chung DC, Beutler AS, Ogino S, Thirlwell C, Shivdasani R, Asa SL, Harris CR, Getz G, Kulke $\mathrm{M}$, Meyerson M. Somatic mutation of CDKN1B in small intestine neuroendocrine tumors. Nat Genet 2013;45:1483-6.

45. Reya T, Morrison SJ, Clarke MF, Weissman IL. Stem cells, cancer, and cancer stem cells. Nature 2001;414:105-11.

46. Al-Hajj M, Wicha MS, Benito-Hernandez A, Morrison SJ, Clarke MF. Prospective identification of tumorigenic breast cancer cells. Proc Natl Acad Sci U S A 2003;100:3983-8.

47. Li C, Heidt DG, Dalerba P, Burant CF, Zhang L, Adsay V, Wicha M, Clarke MF, Simeone DM. Identification of pancreatic cancer stem cells. Cancer Res 2007;67:1030-7.

48. Yang ZF, Ho DW, Ng MN, Lau CK, Yu WC, Ngai P, Chu PW, Lam CT, Poon RT, Fan ST. Significance of CD90+ cancer stem cells in human liver cancer. Cancer Cell 2008;13:153-66.

49. Lapidot T, Sirard C, Vormoor J, Murdoch B, Hoang T, CaceresCortes J, Minden M, Paterson B, Caligiuri MA, Dick JE. A cell initiating human acute myeloid leukaemia after transplantation into SCID mice. Nature 1994;367:645-8

50. Gaur P, Sceusi EL, Samuel S, Xia L, Fan F, Zhou Y, Lu J, Tozzi F, Lopez-Berestein G, Vivas-Mejia P, Rashid A, Fleming JB, Abdalla EK, Curley SA, Vauthey JN, Sood AK, Yao JC, Ellis LM. Identification of cancer stem cells in human gastrointestinal carcinoid and neuroendocrine tumors. Gastroenterology 2011;141:1728-37.

51. Krampitz GW, George BM, Willingham SB, Volkmer JP, Weiskopf K, Jahchan N, Newman AM, Sahoo D, Zemek AJ, Yanovsky RL, Nguyen JK, Schnorr PJ, Mazur PK, Sage J, Longacre TA, Visser BC, Poultsides GA, Norton JA, Weissman IL. Identification of tumorigenic cells and therapeutic targets in pancreatic neuroendocrine tumors. Proc Natl Acad Sci U S A 2016;113:4464-9.

52. Louvi A, Artavanis-Tsakonas S. Notch signalling in vertebrate neural development. Nat Rev Neurosci 2006;7:93-102.

53. Artavanis-Tsakonas S, Rand MD, Lake RJ. Notch signaling: cell fate control and signal integration in development. Science 1999;284:770-6.

54. Kunnimalaiyaan M, Traeger K, Chen H. Conservation of the Notch1 signaling pathway in gastrointestinal carcinoid cells. Am J Physiol Gastrointest Liver Physiol 2005;289:G636-42.

55. Kunnimalaiyaan M, Vaccaro AM, Ndiaye MA, Chen H. Overexpression of the NOTCH1 intracellular domain inhibits cell proliferation and alters the neuroendocrine phenotype of medullary thyroid cancer cells. J Biol Chem 2006;281:39819-30.

56. Nakakura EK, Sriuranpong VR, Kunnimalaiyaan M, Hsiao EC, Schuebel KE, Borges MW, Jin N, Collins BJ, Nelkin BD, Chen $\mathrm{H}$, Ball DW. Regulation of neuroendocrine differentiation in gastrointestinal carcinoid tumor cells by notch signaling. J Clin Endocrinol Metab 2005;90:4350-6.

57. Shida T, Furuya M, Nikaido T, Hasegawa M, Koda K, Oda K, Miyazaki M, Kishimoto T, Nakatani Y, Ishikura H. Sonic HedgehogGli1 signaling pathway might become an effective therapeutic target in gastrointestinal neuroendocrine carcinomas. Cancer Biol Ther 2006;5:1530-8.

58. Wang H, Chen Y, Fernandez-Del Castillo C, Yilmaz O, Deshpande $\mathrm{V}$. Heterogeneity in signaling pathways of gastroenteropancreatic neuroendocrine tumors: a critical look at notch signaling pathway. Mod Pathol 2013;26:139-47.

59. Kao HY, Ordentlich P, Koyano-Nakagawa N, Tang Z, Downes M, Kintner CR, Evans RM, Kadesch T. A histone deacetylase corepressor complex regulates the Notch signal transduction pathway. Genes Dev 1998;12:2269-77.

60. Mulligan P, Yang F, Di Stefano L, Ji JY, Ouyang J, Nishikawa JL, Toiber D, Kulkarni M, Wang Q, Najafi-Shoushtari SH, Mostoslavsky R, Gygi SP, Gill G, Dyson NJ, Naar AM. A SIRT1LSD1 corepressor complex regulates Notch target gene expression and development. Mol Cell 2011;42:689-99.

61. Wang J, Scully K, Zhu X, Cai L, Zhang J, Prefontaine GG, Krones A, Ohgi KA, Zhu P, Garcia-Bassets I, Liu F, Taylor H, Lozach J, Jayes FL, Korach KS, Glass CK, Fu XD, Rosenfeld MG. Opposing LSD1 complexes function in developmental gene activation and repression programmes. Nature 2007;446:882-7.

62. Borggrefe T, Liefke R. Fine-tuning of the intracellular canonical Notch signaling pathway. Cell Cycle 2012;11:264-76.

63. Liefke R, Oswald F, Alvarado C, Ferres-Marco D, Mittler G, Rodriguez P, Dominguez M, Borggrefe T. Histone demethylase KDM5A is an integral part of the core Notch-RBP-J repressor complex. Genes Dev 2010;24:590-601.

64. Miele L. Transcription factor RBPJ/CSL: a genome-wide look at transcriptional regulation. Proc Natl Acad Sci US A 2011;108:14715-6.

65. Wang H, Zou J, Zhao B, Johannsen E, Ashworth T, Wong H, Pear WS, Schug J, Blacklow SC, Arnett KL, Bernstein BE, Kieff E, Aster JC. Genome-wide analysis reveals conserved and divergent features of Notch1/RBPJ binding in human and murine T-lymphoblastic leukemia cells. Proc Natl Acad Sci U S A 2011;108:14908-13.

66. Zhao B, Zou J, Wang H, Johannsen E, Peng CW, Quackenbush J, Mar JC, Morton CC, Freedman ML, Blacklow SC, Aster JC, Bernstein BE, Kieff E. Epstein-Barr virus exploits intrinsic B-lymphocyte transcription programs to achieve immortal cell growth. Proc Natl Acad Sci U S A 2011;108:14902-7.

67. Swarts DR, Ramaekers FC, Speel EJ. Molecular and cellular biology of neuroendocrine lung tumors: evidence for separate biological entities. Biochim Biophys Acta 2012;1826:255-71.

68. Travis WD. The 2015 WHO classification of lung tumors. Pathologe 2014;35 Suppl 2:188.

69. Travis WD, Brambilla E, Burke AP, Marx A, Nicholson AG. WHO 
Classification of Tumours of the Lung, Pleura, Thymus and Heart. 4th edition. In. Lyon France: International Agency for Research on Cancer; 2015.

70. Travis WD. Advances in neuroendocrine lung tumors. Ann Oncol 2010;21 Suppl 7:vii65-71.

71. Detterbeck FC. Management of carcinoid tumors. Ann Thorac Surg 2010;89:998-1005

72. Besse B, Heist RS, Papadmitrakopoulou VA, Camidge DR, Beck JT, Schmid P, Mulatero C, Miller N, Dimitrijevic S, Urva S, Pylvaenaeinen I, Petrovic K, Johnson BE. A phase Ib dose-escalation study of everolimus combined with cisplatin and etoposide as firstline therapy in patients with extensive-stage small-cell lung cancer. Ann Oncol 2014;25:505-11.

73. Pavel ME, Hainsworth JD, Baudin E, Peeters M, Horsch D, Winkler RE, Klimovsky J, Lebwohl D, Jehl V, Wolin EM, Oberg K, Van Cutsem E, Yao JC, Group R-S. Everolimus plus octreotide long-acting repeatable for the treatment of advanced neuroendocrine tumours associated with carcinoid syndrome (RADIANT-2): a randomised, placebo-controlled, phase 3 study. Lancet 2011;378:2005-12.

74. Han JY, Kim HY, Lim KY, Han JH, Lee YJ, Kwak MH, Kim HJ, Yun T, Kim HT, Lee JS. A phase II study of sunitinib in patients with relapsed or refractory small cell lung cancer. Lung Cancer 2013;79:137-42.

75. Johnson BE, Fischer T, Fischer B, Dunlop D, Rischin D, Silberman S, Kowalski MO, Sayles D, Dimitrijevic S, Fletcher C, Hornick J, Salgia R, Le Chevalier T. Phase II study of imatinib in patients with small cell lung cancer. Clin Cancer Res 2003;9:5880-7.

76. Shibata T, Kokubu A, Tsuta K, Hirohashi S. Oncogenic mutation of PIK3CA in small cell lung carcinoma: a potential therapeutic target pathway for chemotherapy-resistant lung cancer. Cancer Lett 2009;283:203-11.

77. Tatematsu A, Shimizu J, Murakami Y, Horio Y, Nakamura S, Hida T, Mitsudomi T, Yatabe Y. Epidermal growth factor receptor mutations in small cell lung cancer. Clin Cancer Res 2008;14:6092-6.

78. Wistuba, II, Gazdar AF, Minna JD. Molecular genetics of small cell lung carcinoma. Semin Oncol 2001;28:3-13.

79. Wakuda K, Kenmotsu H, Serizawa M, Koh Y, Isaka M, Takahashi S, Ono A, Taira T, Naito T, Murakami H, Mori K, Endo M, Nakajima T, Ohde Y, Takahashi T, Yamamoto N. Molecular profiling of small cell lung cancer in a Japanese cohort. Lung Cancer 2014;84:139-44.

80. Iwakawa R, Takenaka M, Kohno T, Shimada Y, Totoki Y, Shibata T, Tsuta K, Nishikawa R, Noguchi M, Sato-Otsubo A, Ogawa S, Yokota J. Genome-wide identification of genes with amplification and/or fusion in small cell lung cancer. Genes Chromosomes Cancer 2013;52:802-16.

81. Peifer M, Fernandez-Cuesta L, Sos ML, George J, Seidel D, Kasper LH, Plenker D, Leenders F, Sun R, Zander T, Menon R, Koker M, Dahmen I, Muller C, Di Cerbo V, Schildhaus HU, Altmuller J, Baessmann I, Becker C, de Wilde B, Vandesompele J, Bohm D, Ansen S, Gabler F, Wilkening I, Heynck S, Heuckmann JM, Lu X, Carter SL, Cibulskis K, Banerji S, Getz G, Park KS, Rauh D, Grutter C, Fischer M, Pasqualucci L, Wright G, Wainer Z, Russell P, Petersen I, Chen Y, Stoelben E, Ludwig C, Schnabel P, Hoffmann H, Muley T, Brockmann M, Engel-Riedel W, Muscarella LA, Fazio VM, Groen H, Timens W, Sietsma H, Thunnissen E, Smit E, Heideman DA, Snijders PJ, Cappuzzo F, Ligorio C, Damiani S, Field J, Solberg S, Brustugun OT, Lund-Iversen M, Sanger J, Clement JH, Soltermann A, Moch H, Weder W, Solomon B, Soria JC, Validire P, Besse B, Brambilla E, Brambilla C, Lantuejoul S, Lorimier P, Schneider PM, Hallek M, Pao W, Meyerson M, Sage J, Shendure J, Schneider R, Buttner R, Wolf J, Nurnberg P, Perner S, Heukamp LC, Brindle PK, Haas S, Thomas RK. Integrative genome analyses identify key somatic driver mutations of small-cell lung cancer. Nat Genet 2012;44:1104-10.

82. Rudin CM, Durinck S, Stawiski EW, Poirier JT, Modrusan Z, Shames DS, Bergbower EA, Guan Y, Shin J, Guillory J, Rivers
CS, Foo CK, Bhatt D, Stinson J, Gnad F, Haverty PM, Gentleman R, Chaudhuri S, Janakiraman V, Jaiswal BS, Parikh C, Yuan W, Zhang Z, Koeppen H, Wu TD, Stern HM, Yauch RL, Huffman KE, Paskulin DD, Illei PB, Varella-Garcia M, Gazdar AF, de Sauvage FJ, Bourgon R, Minna JD, Brock MV, Seshagiri S. Comprehensive genomic analysis identifies SOX2 as a frequently amplified gene in small-cell lung cancer. Nat Genet 2012;44:1111-6.

83. Fernandez-Cuesta L, Peifer M, Lu X, Sun R, Ozretic L, Seidel D, Zander T, Leenders F, George J, Muller C, Dahmen I, Pinther B, Bosco G, Konrad K, Altmuller J, Nurnberg P, Achter V, Lang U, Schneider PM, Bogus M, Soltermann A, Brustugun OT, Helland A, Solberg S, Lund-Iversen M, Ansen S, Stoelben E, Wright GM, Russell P, Wainer Z, Solomon B, Field JK, Hyde R, Davies MP, Heukamp LC, Petersen I, Perner S, Lovly CM, Cappuzzo F, Travis WD, Wolf J, Vingron M, Brambilla E, Haas SA, Buettner R, Thomas RK. Frequent mutations in chromatin-remodelling genes in pulmonary carcinoids. Nat Commun 2014;5:3518.

84. George J, Lim JS, Jang SJ, Cun Y, Ozretic L, Kong G, Leenders F, Lu X, Fernandez-Cuesta L, Bosco G, Muller C, Dahmen I, Jahchan NS, Park KS, Yang D, Karnezis AN, Vaka D, Torres A, Wang MS, Korbel JO, Menon R, Chun SM, Kim D, Wilkerson M, Hayes N, Engelmann D, Putzer B, Bos M, Michels S, Vlasic I, Seidel D, Pinther B, Schaub P, Becker C, Altmuller J, Yokota J, Kohno T, Iwakawa R, Tsuta K, Noguchi M, Muley T, Hoffmann H, Schnabel PA, Petersen I, Chen Y, Soltermann A, Tischler V, Choi CM, Kim YH, Massion PP, Zou Y, Jovanovic D, Kontic M, Wright GM, Russell PA, Solomon B, Koch I, Lindner M, Muscarella LA, la Torre A, Field JK, Jakopovic M, Knezevic J, Castanos-Velez E, Roz L, Pastorino U, Brustugun OT, Lund-Iversen M, Thunnissen E, Kohler J, Schuler M, Botling J, Sandelin M, Sanchez-Cespedes M, Salvesen HB, Achter V, Lang U, Bogus M, Schneider PM, Zander T, Ansen S, Hallek M, Wolf J, Vingron M, Yatabe Y, Travis WD, Nurnberg P, Reinhardt C, Perner S, Heukamp L, Buttner R, Haas SA, Brambilla E, Peifer M, Sage J, Thomas RK. Comprehensive genomic profiles of small cell lung cancer. Nature 2015;524:47-53.

85. Salcido CD, Larochelle A, Taylor BJ, Dunbar CE, Varticovski L. Molecular characterisation of side population cells with cancer stem cell-like characteristics in small-cell lung cancer. Br J Cancer 2010;102:1636-44.

86. Wang P, Gao Q, Suo Z, Munthe E, Solberg S, Ma L, Wang M, Westerdaal NA, Kvalheim G, Gaudernack G. Identification and characterization of cells with cancer stem cell properties in human primary lung cancer cell lines. PLoS One 2013;8:e57020.

87. Eramo A, Lotti F, Sette G, Pilozzi E, Biffoni M, Di Virgilio A, Conticello C, Ruco L, Peschle C, De Maria R. Identification and expansion of the tumorigenic lung cancer stem cell population. Cell Death Differ 2008;15:504-14.

88. Qiu X, Wang Z, Li Y, Miao Y, Ren Y, Luan Y. Characterization of sphere-forming cells with stem-like properties from the small cell lung cancer cell line H446. Cancer Lett 2012;323:161-70.

89. Roudi R, Korourian A, Shariftabrizi A, Madjd Z. Differential expression of cancer stem cell markers ALDH1 and CD133 in various lung cancer subtypes. Cancer Invest 2015;33:294-302.

90. Sarvi S, Mackinnon AC, Avlonitis N, Bradley M, Rintoul RC, Rassl DM, Wang W, Forbes SJ, Gregory CD, Sethi T. CD133+ cancer stem-like cells in small cell lung cancer are highly tumorigenic and chemoresistant but sensitive to a novel neuropeptide antagonist. Cancer Res 2014;74:1554-65

91. Wang B, Yang H, Huang YZ, Yan RH, Liu FJ, Zhang JN. Biologic characteristics of the side population of human small cell lung cancer cell line H446. Chin J Cancer 2010;29:254-60.

92. Zhang Z, Zhou Y, Qian H, Shao G, Lu X, Chen Q, Sun X, Chen D, Yin $\mathrm{R}$, Zhu H, Shao Q, Xu W. Stemness and inducing differentiation of small cell lung cancer NCI-H446 cells. Cell Death Dis 2013;4:e633.

93. Kolev VN, Wright QG, Vidal CM, Ring JE, Shapiro IM, Ricono J, Weaver DT, Padval MV, Pachter JA, Xu Q. PI3K/mTOR dual 
inhibitor VS-5584 preferentially targets cancer stem cells. Cancer Res 2015;75:446-55.

94. Eliasz S, Liang S, Chen Y, De Marco MA, Machek O, Skucha S, Miele L, Bocchetta M. Notch-1 stimulates survival of lung adenocarcinoma cells during hypoxia by activating the IGF-1R pathway. Oncogene 2010;29:2488-98.

95. Sriuranpong V, Borges MW, Ravi RK, Arnold DR, Nelkin BD, Baylin SB, Ball DW. Notch signaling induces cell cycle arrest in small cell lung cancer cells. Cancer Res 2001;61:3200-5.

96. Zhou M, Jin WY, Fan ZW, Han RC. Analysis of the expression of the Notch3 receptor protein in adult lung cancer. Oncol Lett 2013;5:499-504.

97. Ito T, Udaka N, Yazawa T, Okudela K, Hayashi H, Sudo T, Guillemot F, Kageyama R, Kitamura H. Basic helix-loop-helix transcription factors regulate the neuroendocrine differentiation of fetal mouse pulmonary epithelium. Development 2000;127:3913-21.

98. Morimoto M, Nishinakamura R, Saga Y, Kopan R. Different assemblies of Notch receptors coordinate the distribution of the major bronchial Clara, ciliated and neuroendocrine cells. Development 2012;139:4365-73.

99. Yen WC, Fischer MM, Axelrod F, Bond C, Cain J, Cancilla B, Henner WR, Meisner R, Sato A, Shah J, Tang T, Wallace B, Wang M, Zhang C, Kapoun AM, Lewicki J, Gurney A, Hoey T. Targeting Notch signaling with a Notch2/Notch3 antagonist (tarextumab) inhibits tumor growth and decreases tumor-initiating cell frequency. Clin Cancer Res 2015;21:2084-95.

100. Graziani I, Eliasz S, De Marco MA, Chen Y, Pass HI, De May RM, Strack PR, Miele L, Bocchetta M. Opposite effects of Notch-1 and Notch-2 on mesothelioma cell survival under hypoxia are exerted through the Akt pathway. Cancer Res 2008;68:9678-85.

101. Yun J, Pannuti A, Espinoza I, Zhu H, Hicks C, Zhu X, Caskey M, Rizzo P, D’Souza G, Backus K, Denning MF, Coon J, Sun M, Bresnick EH, Osipo C, Wu J, Strack PR, Tonetti DA, Miele L. Crosstalk between PKCalpha and Notch-4 in endocrine-resistant breast cancer cells. Oncogenesis 2013;2:e60.

102. Parr C, Watkins G, Jiang WG. The possible correlation of Notch-1 and Notch-2 with clinical outcome and tumour clinicopathological parameters in human breast cancer. Int J Mol Med 2004;14:779-86.

103. Sun J, Deng WM. Notch-dependent downregulation of the homeodomain gene cut is required for the mitotic cycle/endocycle switch and cell differentiation in Drosophila follicle cells. Development 2005;132:4299-308.

104. Osipo C, Golde TE, Osborne BA, Miele LA. Off the beaten pathway: the complex cross talk between Notch and NF-kappaB. Lab Invest 2008; $88: 11-7$

105. Raafat A, Lawson S, Bargo S, Klauzinska M, Strizzi L, Goldhar AS, Buono K, Salomon D, Vonderhaar BK, Callahan R. Rbpj conditional knockout reveals distinct functions of Notch4/Int3 in mammary gland development and tumorigenesis. Oncogene 2009;28:219-30.

106. Robinson DR, Kalyana-Sundaram S, Wu YM, Shankar S, Cao X, Ateeq B, Asangani IA, Iyer M, Maher CA, Grasso CS, Lonigro RJ, Quist M, Siddiqui J, Mehra R, Jing X, Giordano TJ, Sabel MS, Kleer CG, Palanisamy N, Natrajan R, Lambros MB, ReisFilho JS, Kumar-Sinha C, Chinnaiyan AM. Functionally recurrent rearrangements of the MAST kinase and Notch gene families in breast cancer. Nat Med 2011;17:1646-51.

107. Heath M, Jaimes N, Lemos B, Mostaghimi A, Wang LC, Penas PF, Nghiem P. Clinical characteristics of Merkel cell carcinoma at diagnosis in 195 patients: the AEIOU features. J Am Acad Dermatol 2008:58:375-81.

108. Albores-Saavedra J, Batich K, Chable-Montero F, Sagy N, Schwartz AM, Henson DE. Merkel cell carcinoma demographics, morphology, and survival based on 3870 cases: a population based study. J Cutan Pathol 2010;37:20-7.

109. Miller NJ, Bhatia S, Parvathaneni U, Iyer JG, Nghiem P. Emerging and mechanism-based therapies for recurrent or metastatic Merkel cell carcinoma. Curr Treat Options Oncol 2013;14:249-63.

110. Samimi M, Touze A. Merkel cell carcinoma: The first human cancer shown to be associated with a polyomavirus. Presse Med 2014;43:e405-11.

111. Feng H, Shuda M, Chang Y, Moore PS. Clonal integration of a polyomavirus in human Merkel cell carcinoma. Science 2008;319:1096-100.

112. Shuda M, Feng H, Kwun HJ, Rosen ST, Gjoerup O, Moore PS, Chang Y. T antigen mutations are a human tumor-specific signature for Merkel cell polyomavirus. Proc Natl Acad Sci U S A 2008; $105: 16272-7$.

113. Shuda M, Kwun HJ, Feng H, Chang Y, Moore PS. Human Merkel cell polyomavirus small $\mathrm{T}$ antigen is an oncoprotein targeting the 4E-BP1 translation regulator. $J$ Clin Invest 2011;121:3623-34.

114. Goh G, Walradt T, Markarov V, Blom A, Riaz N, Doumani R, Stafstrom K, Moshiri A, Yelistratova L, Levinsohn J, Chan TA, Nghiem P, Lifton RP, Choi J. Mutational landscape of MCPyVpositive and MCPyV-negative Merkel cell carcinomas with implications for immunotherapy. Oncotarget 2016;7:3403-15.

115. Harms PW, Vats P, Verhaegen ME, Robinson DR, Wu YM, Dhanasekaran SM, Palanisamy N, Siddiqui J, Cao X, Su F, Wang R, Xiao H, Kunju LP, Mehra R, Tomlins SA, Fullen DR, Bichakjian CK, Johnson TM, Dlugosz AA, Chinnaiyan AM. The Distinctive Mutational Spectra of Polyomavirus-Negative Merkel Cell Carcinoma. Cancer Res 2015;75:3720-7.

116. Lemos BD, Storer BE, Iyer JG, Phillips JL, Bichakjian CK, Fang LC, Johnson TM, Liegeois-Kwon NJ, Otley CC, Paulson KG, Ross MI, Yu SS, Zeitouni NC, Byrd DR, Sondak VK, Gershenwald JE, Sober AJ, Nghiem P. Pathologic nodal evaluation improves prognostic accuracy in Merkel cell carcinoma: analysis of 5823 cases as the basis of the first consensus staging system. J Am Acad Dermatol 2010;63:751-61.

117. Lemos B, Nghiem P. Merkel cell carcinoma: more deaths but still no pathway to blame. J Invest Dermatol 2007;127:2100-3.

118. Mauzo SH, Ferrarotto R, Bell D, Torres-Cabala CA, Tetzlaff MT, Prieto VG, Aung PP. Molecular characteristics and potential therapeutic targets in Merkel cell carcinoma. J Clin Pathol 2016;69:382-90.

119. Iyer JG, Parvathaneni U, Gooley T, Miller NJ, Markowitz E, Blom A, Lewis CW, Doumani RF, Parvathaneni K, Anderson A, Bestick A, Liao J, Kane G, Bhatia S, Paulson K, Nghiem P. Single-fraction radiation therapy in patients with metastatic Merkel cell carcinoma. Cancer Med 2015;4:1161-70.

120. Lebbe C, Becker JC, Grob JJ, Malvehy J, Del Marmol V, Pehamberger H, Peris K, Saiag P, Middleton MR, Bastholt L, Testori A, Stratigos A, Garbe C, European Dermatology Forum tEAoD-O, the European Organization for R, Treatment of C. Diagnosis and treatment of Merkel Cell Carcinoma. European consensus-based interdisciplinary guideline. Eur J Cancer 2015;51:2396-403.

121. Poulsen M, Rischin D, Walpole E, Harvey J, Mackintosh J, Ainslie J, Hamilton C, Keller J, Tripcony L, Trans-Tasman Radiation Oncology G. High-risk Merkel cell carcinoma of the skin treated with synchronous carboplatin/etoposide and radiation: a TransTasman Radiation Oncology Group Study -- TROG 96:07. J Clin Oncol 2003;21:4371-6.

122. Tai PT, Yu E, Winquist E, Hammond A, Stitt L, Tonita J, Gilchrist J. Chemotherapy in neuroendocrine/Merkel cell carcinoma of the skin: case series and review of 204 cases. J Clin Oncol 2000;18:2493-9.

123. Fakiha M, Letertre P, Vuillez JP, Lebeau J. Remission of Merkel cell tumor after somatostatin analog treatment. $J$ Cancer Res Ther 2010;6:382-4.

124. Gardair C, Samimi M, Touze A, Coursaget P, Lorette G, Caille A, Wierzbicka E, Croue A, Avenel-Audran M, Aubin F, Kerdraon R, Esteve E, Beneton N, Guyetant S. Somatostatin receptors $2 \mathrm{~A}$ and 5 are expressed in Merkel cell carcinoma with no association with disease severity. Neuroendocrinology 2015;101:223-35.

125. Davids MS, Charlton A, Ng SS, Chong ML, Laubscher K, Dar M, 
Hodge J, Soong R, Goh BC. Response to a novel multitargeted tyrosine kinase inhibitor pazopanib in metastatic Merkel cell carcinoma. J Clin Oncol 2009;27:e97-100.

126. Hafner C, Houben R, Baeurle A, Ritter C, Schrama D, Landthaler $\mathrm{M}$, Becker JC. Activation of the PI3K/AKT pathway in Merkel cell carcinoma. PLoS One 2012; 7:e31255.

127. Nardi V, Song Y, Santamaria-Barria JA, Cosper AK, Lam Q, Faber AC, Boland GM, Yeap BY, Bergethon K, Scialabba VL, Tsao H, Settleman J, Ryan DP, Borger DR, Bhan AK, Hoang MP, Iafrate AJ, Cusack JC, Engelman JA, Dias-Santagata D. Activation of PI3K signaling in Merkel cell carcinoma. Clin Cancer Res 2012;18:1227-36.

128. Samimi M, Touze A, Laude H, Le Bidre E, Arnold F, Carpentier A, Gardair C, Carlotti A, Maubec E, Dupin N, Aubin F, Avril MF, Rozenberg F, Avenel-Audran M, Guyetant S, Lorette G, Machet L, Coursaget P. Vitamin D deficiency is associated with greater tumor size and poorer outcome in Merkel cell carcinoma patients. $J$ Eur Acad Dermatol Venereol 2014;28:298-308.

129. Batinica M, Akgul B, Silling S, Mauch C, Zigrino P. Correlation of Merkel cell polyomavirus positivity with PDGFRalpha mutations and survivin expression in Merkel cell carcinoma. J Dermatol Sci 2015;79:43-9.

130. Tolcher AW, Mita A, Lewis LD, Garrett CR, Till E, Daud AI, Patnaik A, Papadopoulos K, Takimoto C, Bartels P, Keating A, Antonia S. Phase I and pharmacokinetic study of YM155, a small-molecule inhibitor of survivin. J Clin Oncol 2008;26:5198-203.

131. Lipson EJ, Vincent JG, Loyo M, Kagohara LT, Luber BS, Wang H, Xu H, Nayar SK, Wang TS, Sidransky D, Anders RA, Topalian SL, Taube JM. PD-L1 expression in the Merkel cell carcinoma microenvironment: association with inflammation, Merkel cell polyomavirus and overall survival. Cancer Immunol Res 2013;1:54-63.

132. Whiteman KR, Johnson HA, Mayo MF, Audette CA, Carrigan CN, LaBelle A, Zukerberg L, Lambert JM, Lutz RJ. Lorvotuzumab mertansine, a CD56-targeting antibody-drug conjugate with potent antitumor activity against small cell lung cancer in human xenograft models. MAbs 2014;6:556-66.

133. Veija T, Sarhadi VK, Koljonen V, Bohling T, Knuutila S. Hotspot mutations in polyomavirus positive and negative Merkel cell carcinomas. Cancer Genet 2016;209:30-5.

134. Cohen PR, Tomson BN, Elkin SK, Marchlik E, Carter JL, Kurzrock R. Genomic portfolio of Merkel cell carcinoma as determined by comprehensive genomic profiling: implications for targeted therapeutics. Oncotarget 201610.18632/oncotarget.8032.

135. Cimino PJ, Robirds DH, Tripp SR, Pfeifer JD, Abel HJ, Duncavage EJ. Retinoblastoma gene mutations detected by whole exome sequencing of Merkel cell carcinoma. Mod Pathol 2014;27:1073-87.

136. Graves CA, Jones A, Reynolds J, Stuart J, Pirisi L, Botrous P, Wells J. Neuroendocrine Merkel cell carcinoma is associated with mutations in key DNA repair, epigenetic and apoptosis pathways: a case-based study using targeted massively parallel sequencing. Neuroendocrinology 2015;101:112-9.

137. Harms PW, Collie AM, Hovelson DH, Cani AK, Verhaegen ME, Patel RM, Fullen DR, Omata K, Dlugosz AA, Tomlins SA, Billings SD. Next generation sequencing of Cytokeratin 20-negative Merkel cell carcinoma reveals ultraviolet-signature mutations and recurrent TP53 and RB1 inactivation. Mod Pathol 2016;29:240-8.

138. Tilling T, Moll I. Which are the cells of origin in merkel cell carcinoma? J Skin Cancer 2012;2012:680410.

139. McCardle TW, Sondak VK, Zager J, Messina JL. Merkel cell carcinoma: pathologic findings and prognostic factors. Curr Probl Cancer 2010;34:47-64.

140. Zur Hausen A, Rennspiess D, Winnepenninckx V, Speel EJ, Kurz AK. Early B-cell differentiation in Merkel cell carcinomas: clues to cellular ancestry. Cancer Res 2013;73:4982-7.

141. Abraham KJ, Zhang X, Vidal R, Pare GC, Feilotter HE, Tron VA. Roles for miR-375 in neuroendocrine differentiation and tumor suppression via Notch pathway suppression in Merkel cell carcinoma. Am J Pathol 201610.1016/j.ajpath.2015.11.020.

142. Panelos J, Batistatou A, Paglierani M, Zioga A, Maio V, Santi R, Pimpinelli N, De Giorgi V, Santucci M, Massi D. Expression of Notch-1 and alteration of the E-cadherin/beta-catenin cell adhesion complex are observed in primary cutaneous neuroendocrine carcinoma (Merkel cell carcinoma). Mod Pathol 2009;22:959-68.

143. Viola D, Valerio L, Molinaro E, Agate L, Bottici V, Biagini A, Lorusso L, Cappagli V, Pieruzzi L, Giani C, Sabini E, Passannati P, Puleo L, Matrone A, Pontillo-Contillo B, Battaglia V, Mazzeo S, Vitti P, Elisei R. Treatment of advanced thyroid cancer with targeted therapies: ten years of experience. Endocr Relat Cancer 2016;23:R185-205.

144. Elisei R, Pinchera A. Advances in the follow-up of differentiated or medullary thyroid cancer. Nat Rev Endocrinol 2012;8:466-75.

145. Donis-Keller H, Dou S, Chi D, Carlson KM, Toshima K, Lairmore TC, Howe JR, Moley JF, Goodfellow P, Wells SA, Jr. Mutations in the RET proto-oncogene are associated with MEN 2A and FMTC. Hum Mol Genet 1993;2:851-6.

146. Mulligan LM, Kwok JB, Healey CS, Elsdon MJ, Eng C, Gardner E, Love DR, Mole SE, Moore JK, Papi L, Ponder MA, Telenius $\mathrm{H}$, Tunnacliffe A, Ponder BAJ. Germ-line mutations of the RET proto-oncogene in multiple endocrine neoplasia type 2A. Nature 1993;363:458-60.

147. Ciampi R, Mian C, Fugazzola L, Cosci B, Romei C, Barollo S, Cirello V, Bottici V, Marconcini G, Rosa PM, Borrello MG, Basolo F, Ugolini C, Materazzi G, Pinchera A, Elisei R. Evidence of a low prevalence of RAS mutations in a large medullary thyroid cancer series. Thyroid 2013;23:50-7.

148. Agrawal N, Jiao Y, Sausen M, Leary R, Bettegowda C, Roberts NJ, Bhan S, Ho AS, Khan Z, Bishop J, Westra WH, Wood LD, Hruban RH, Tufano RP, Robinson B, Dralle H, Toledo SP, Toledo RA, Morris LG, Ghossein RA, Fagin JA, Chan TA, Velculescu VE, Vogelstein B, Kinzler KW, Papadopoulos N, Nelkin BD, Ball DW. Exomic sequencing of medullary thyroid cancer reveals dominant and mutually exclusive oncogenic mutations in RET and RAS. $J$ Clin Endocrinol Metab 2013;98:E364-9.

149. Schneider TC, de Wit D, Links TP, van Erp NP, van der Hoeven JJ, Gelderblom H, van Wezel T, van Eijk R, Morreau H, Guchelaar HJ, Kapiteijn E. Beneficial Effects of the mTOR Inhibitor Everolimus in Patients with Advanced Medullary Thyroid Carcinoma: Subgroup Results of a Phase II Trial. Int J Endocrinol 2015;2015:348124.

150. Lim SM, Chang H, Yoon MJ, Hong YK, Kim H, Chung WY, Park CS, Nam KH, Kang SW, Kim MK, Kim SB, Lee SH, Kim HG, Na, II, Kim YS, Choi MY, Kim JG, Park KU, Yun HJ, Kim JH, Cho BC. A multicenter, phase II trial of everolimus in locally advanced or metastatic thyroid cancer of all histologic subtypes. Ann Oncol 2013;24:3089-94.

151. Lin SF, Huang YY, Lin JD, Chou TC, Hsueh C, Wong RJ. Utility of a PI3K/mTOR inhibitor (NVP-BEZ235) for thyroid cancer therapy. PLoS One 2012;7:e46726.

152. Juweid ME, Hajjar G, Stein R, Sharkey RM, Herskovic T, Swayne LC, Suleiman S, Pereira M, Rubin AD, Goldenberg DM. Initial experience with high-dose radioimmunotherapy of metastatic medullary thyroid cancer using 131I-MN-14 F(ab)2 anti-carcinoembryonic antigen MAb and AHSCR. J Nucl Med 2000;41:93-103.

153. Schlumberger MJ, Elisei R, Bastholt L, Wirth LJ, Martins RG, Locati LD, Jarzab B, Pacini F, Daumerie C, Droz JP, Eschenberg MJ, Sun YN, Juan T, Stepan DE, Sherman SI. Phase II study of safety and efficacy of motesanib in patients with progressive or symptomatic, advanced or metastatic medullary thyroid cancer. $J$ Clin Oncol 2009;27:3794-801.

154. Locati LD, Licitra L, Agate L, Ou SH, Boucher A, Jarzab B, Qin S, Kane MA, Wirth LJ, Chen C, Kim S, Ingrosso A, Pithavala YK, Bycott P, Cohen EE. Treatment of advanced thyroid cancer with axitinib: Phase 2 study with pharmacokinetic/pharmacodynamic and quality-of-life assessments. Cancer 2014;120:2694-703. 
155. Wells SA, Jr., Robinson BG, Gagel RF, Dralle H, Fagin JA, Santoro M, Baudin E, Elisei R, Jarzab B, Vasselli JR, Read J, Langmuir P, Ryan AJ, Schlumberger MJ. Vandetanib in patients with locally advanced or metastatic medullary thyroid cancer: a randomized, double-blind phase III trial. J Clin Oncol 2012;30:134-41.

156. Elisei R, Schlumberger MJ, Muller SP, Schoffski P, Brose MS, Shah MH, Licitra L, Jarzab B, Medvedev V, Kreissl MC, Niederle B, Cohen EE, Wirth LJ, Ali H, Hessel C, Yaron Y, Ball D, Nelkin B, Sherman SI. Cabozantinib in progressive medullary thyroid cancer. J Clin Oncol 2013;31:3639-46.

157. Spitzweg C, Morris JC, Bible KC. New drugs for medullary thyroid cancer: new promises? Endocr Relat Cancer 201610.1530/ERC16-0104.

158. Cai J, Li L, Ye L, Jiang X, Shen L, Gao Z, Fang W, Huang F, Su T, Zhou Y, Wang W, Ning G. Exome sequencing reveals mutant genes with low penetrance involved in MEN2A-associated tumorigenesis. Endocr Relat Cancer 2015;22:23-33.

159. Smith J, Read ML, Hoffman J, Brown R, Bradshaw B, Campbell C, Cole T, Navas JD, Eatock F, Gundara JS, Lian E, McMullan D, Morgan NV, Mulligan L, Morrison PJ, Robledo M, Simpson MA, Smith VE, Stewart S, Trembath RC, Sidhu S, Togneri FS, Wake NC, Wallis Y, Watkinson JC, Maher ER, McCabe CJ, Woodward ER. Germline ESR2 mutation predisposes to medullary thyroid carcinoma and causes up-regulation of RET expression. Hum Mol Genet 2016;25:1836-45.

160. Jonsson P, Katchy A, Williams C. Support of a bi-faceted role of estrogen receptor beta (ERbeta) in ERalpha-positive breast cancer cells. Endocr Relat Cancer 2014;21:143-60.

161. Horimoto Y, Hartman J, Millour J, Pollock S, Olmos Y, Ho KK, Coombes RC, Poutanen M, Makela SI, El-Bahrawy M, Speirs V, Lam EW. ERbeta1 represses FOXM1 expression through targeting ERalpha to control cell proliferation in breast cancer. Am J Pathol 2011;179:1148-56.

162. Williams C, Edvardsson K, Lewandowski SA, Strom A, Gustafsson JA. A genome-wide study of the repressive effects of estrogen receptor beta on estrogen receptor alpha signaling in breast cancer cells. Oncogene 2008;27:1019-32.

163. Chang EC, Frasor J, Komm B, Katzenellenbogen BS. Impact of estrogen receptor beta on gene networks regulated by estrogen receptor alpha in breast cancer cells. Endocrinology 2006;147:4831-42.

164. Heilmann AM, Subbiah V, Wang K, Sun JX, Elvin JA, Chmielecki J, Sherman SI, Murthy R, Busaidy NL, Subbiah I, Yelensky R, Nangia
C, Vergilio JA, Khan SA, Erlich RL, Lipson D, Ross JS, Miller VA, Shah MH, Ali SM, Stephens PJ. Comprehensive genomic profiling of clinically advanced medullary thyroid carcinoma. Oncology 2016;90:339-46.

165. Zhu W, Hai T, Ye L, Cote GJ. Medullary thyroid carcinoma cell lines contain a self-renewing $\mathrm{CD} 133+$ population that is dependent on ret proto-oncogene activity. J Clin Endocrinol Metab 2010;95:439-44.

166. Kucerova L, Feketeova L, Kozovska Z, Poturnajova M, Matuskova $\mathrm{M}$, Nencka R, Babal P. In vivo 5FU-exposed human medullary thyroid carcinoma cells contain a chemoresistant CD133+ tumorinitiating cell subset. Thyroid 2014;24:520-32.

167. Tang M, Hou YL, Kang QQ, Chen XY, Duan LQ, Shu J, Li SL, Hu XL, Peng ZP. All-trans-retinoic acid promotes iodine uptake via upregulating the sodium iodide symporter in medullary thyroid cancer stem cells. Asian Pac J Cancer Prev 2014;15:1859-62.

168. Bi Y, Meng Y, Wu H, Cui Q, Luo Y, Xue X. Expression of the potential cancer stem cell markers CD133 and CD44 in medullary thyroid carcinoma: A ten-year follow-up and prognostic analysis. $J$ Surg Oncol 2016;113:144-51.

169. Stockhausen MT, Sjolund J, Manetopoulos C, Axelson H. Effects of the histone deacetylase inhibitor valproic acid on Notch signalling in human neuroblastoma cells. Br J Cancer 2005;92:751-9.

170. Greenblatt DY, Cayo MA, Adler JT, Ning L, Haymart MR, Kunnimalaiyaan M, Chen H. Valproic acid activates Notch1 signaling and induces apoptosis in medullary thyroid cancer cells. Ann Surg 2008;247:1036-40.

171. Jaskula-Sztul R, Pisarnturakit P, Landowski M, Chen H, Kunnimalaiyaan M. Expression of the active Notch1 decreases MTC tumor growth in vivo. J Surg Res 2011;171:23-7.

172. Jaskula-Sztul R, Eide J, Tesfazghi S, Dammalapati A, Harrison AD, Yu XM, Scheinebeck C, Winston-McPherson G, Kupcho KR, Robers MB, Hundal AK, Tang W, Chen H. Tumor-suppressor role of Notch3 in medullary thyroid carcinoma revealed by genetic and pharmacological induction. Mol Cancer Ther 2015;14:499-512.

173. Truong M, Cook MR, Pinchot SN, Kunnimalaiyaan M, Chen H. Resveratrol induces Notch2-mediated apoptosis and suppression of neuroendocrine markers in medullary thyroid cancer. Ann Surg Oncol 2011;18:1506-11.

174. Tesfazghi S, Eide J, Dammalapati A, Korlesky C, Wyche TP, Bugni TS, Chen H, Jaskula-Sztul R. Thiocoraline alters neuroendocrine phenotype and activates the Notch pathway in MTC-TT cell line. Cancer Med 2013;2:734-43. 